\title{
Recent Trends in Field-Effect Transistors-Based Immunosensors
}

\author{
Ana Carolina Mazarin de Moraes and Lauro Tatsuo Kubota * \\ Department of Analytical Chemistry, Institute of Chemistry, University of Campinas, P.O. Box 6154, Campinas, \\ São Paulo 13083-970, Brazil; anacmmo@gmail.com \\ * Correspondence: kubota@iqm.unicamp.br; Tel.: +55-19-3521-2134
}

Academic Editors: Paolo Ugo and Ligia Moretto

Received: 29 July 2016; Accepted: 12 October 2016; Published: 21 October 2016

\begin{abstract}
Immunosensors are analytical platforms that detect specific antigen-antibody interactions and play an important role in a wide range of applications in biomedical clinical diagnosis, food safety, and monitoring contaminants in the environment. Field-effect transistors (FET) immunosensors have been developed as promising alternatives to conventional immunoassays, which require complicated processes and long-time data acquisition. The electrical signal of FET-based immunosensors is generated as a result of the antigen-antibody conjugation. FET biosensors present real-time and rapid response, require small sample volume, and exhibit higher sensitivity and selectivity. This review brings an overview on the recent literature of FET-based immunosensors, highlighting a diversity of nanomaterials modified with specific receptors as immunosensing platforms for the ultrasensitive detection of various biomolecules.
\end{abstract}

Keywords: biosensors; immunosensors; field-effect transistors; immunoFET; antigen-antibody; nanomaterials

\section{Introduction to Immunosensors}

Biosensors are defined as analytical devices combining functional materials or biological elements for the selective detection of an analyte. The recognition system consists of biological receptors, for instance: enzymes, cellular receptors, antibodies, nucleic acids, microorganisms, or artificial biomimetic materials, all equipped with biochemical mechanisms for recognition. Moreover, these biodevices are capable of providing quantitative or semi-quantitative analytical information by forming specific biological recognition complexes such as enzyme-substrate, antigen-antibody, etc., which are able to convert the biochemical changes into a measurable signal by means of a physicochemical transducer system [1,2]. Immunosensors are biosensors that detect either the sensitive biological elements antibodies or antigens through the event of formation of specific antigen-antibody complexes. The detection of antibodies is preferred and these biological elements are often properly immobilized on the surface of the transducer [3].

An antibody (Figure 1, top-left inset) is a large protein in a " $Y$ " shape that consists of highly ordered sequences of hundreds of amino acids. Specifically, the antibody molecule structure is composed of two heavy polypeptide chains (molecular weights of $50 \mathrm{kDa}$ ) and two light chains (molecular weights of $25 \mathrm{kDa}$ ) linked by disulfide bonds. The chains have both constant and variable regions and the antigen-binding takes place at light and heavy variable domains, forming the hyper-variable regions of the antibody, known as the complementarity determining regions (CDR). The constant region is generally preserved from one antibody to another class, while the CDR show a great diversity of sequences $[4,5]$. 


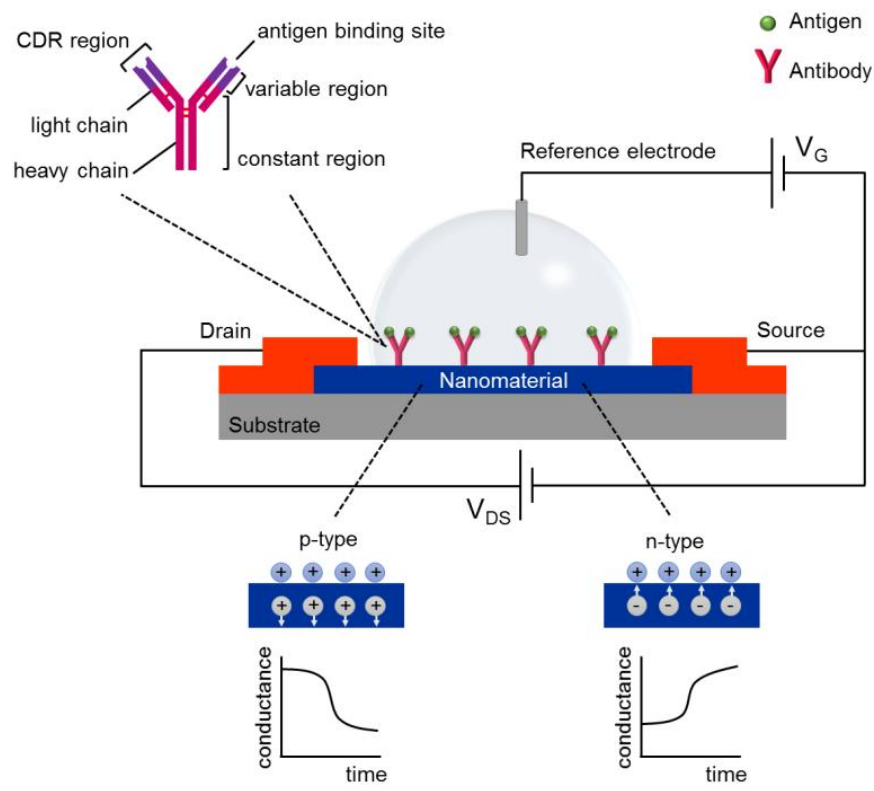

Figure 1. Scheme outlining an immunoFET operating in solution. Top-left inset represents an antibody structure, which is basically composed of two light and two heavy chains linked by disulfide bonds (red lines). Nanomaterials are embedded on the gate region as the semiconductor channel of a FET-based biosensor. Specific antibodies for antigen recognition are immobilized on the nanomaterial surface. The binding of positively charged target molecules on a p-type channel causes depletion of charge carriers (holes) and decrease in conductance, while in an n-type channel, the positively charged molecules result in accumulation of charge carriers (electrons) and increase in conductance.

Antibodies are glycoproteins produced by the immune system to identify and neutralize foreign substances to the body, known as antigens. Antigens are molecules or particles capable of initiating an immune response, therefore triggering the production of antibodies. The antibodies, in turn, identify and bind to antigens with extremely high specificity, and a minor change in the chemical structure of an antigen can dramatically reduce its affinity for an antibody. Thus, the antibody must be specific, have a stable and strong interaction with the antigen, and be able to detect the target analyte at the required concentration range, ensuring the sensitivity and reliability of an immunosensor [5-8].

Polyclonal antibodies are generated by multiple immune cells and can bind to the antigen target through a large number of epitopes (specific antigen regions where antibodies bind). Polyclonal antibodies are cheap and facile to produce, however they lack specificity. Monoclonal antibodies are produced from immune cells identical to the parent cells and recognize specific epitopes of an antigen, thus conferring higher selectivity than polyclonal. There is a plethora of commercially available antibodies and their production is generally mediated by immunizing an animal with a foreign infection to produce an immune response [5,9].

Immunosensors may be useful to monitor and quantify the functioning of the immune system, detecting the presence of specific antibodies or antigens in body fluids; therefore, they can be considered as promising tools in clinical diagnosis applications. The analytes may also include microorganisms such as viruses and bacteria, which find an important role in food safety, and pollutants such as pesticides and herbicides, that are valuable in environmental monitoring.

Immunosensors can be divided in two groups: labeled and label-free. The labeled immunosensors are designed in a way that the immunoreaction is measured through the detection of the labeling of a molecule with labels such as luminescent, fluorescent, radioactive, and epitope tags [3]. For example, the most utilized enzyme immunoassay in clinical analysis and residual analysis in environmental and food samples is the label-based enzyme-linked immunosorbent assay (ELISA) [10]. The ELISA test basically consists of translating the recognition event between a specific enzyme-labeled antibody and 
an antigen into a colorimetric, chemiluminescent, or electrochemical signal [11,12]. Radioimmunoassay (RIA) is also used in clinical diagnosis and involves the use of radiolabeled antigens or antibodies [13]. Despite the reliability and high sensitivity of conventional immunoassays, they suffer from drawbacks such as the demand for relatively large volumes of sample, long incubation periods, complicated laboratory apparatus, needing to be carried out by highly trained laboratory staff, and requiring multiple labeling strategies that would not interfere with the antigen-antibody interactions [5]. On the other hand, the label-free immunosensors allow the direct monitoring of immunoreactions by measuring physicochemical changes induced by the antigen-antibody complex formation, being more attractive as alternatives amongst traditional immunoassays.

The transduction platforms convert the chemical or physical changes induced by selective antigen-antibody interactions into a quantifiable signal. Signal transducing can be performed by different transducing mechanisms. The most employed transducers in immunosensors are related to the measurement of electrons, photons, and masses, thus including electrochemical, optical, and piezoelectric systems, respectively. Biodevices based on electrochemical transducing platforms are the most exploited so far because of their simple principle of measurement. The antigen-antibody complex formation generates an electrical signal that can be measured by different means. In general terms, electrochemical transducers comprise: amperometric/voltammetric, conductimetric, potentiometric, impedance, and semiconductor field-effect principles; which measure changes in: current, modulation of conductance, potential or charge accumulation, electrical impedance, and either the current or the potential across a semiconductor in response of a binding process at the gate surface, respectively [9].

The optical transducers operate by means of an optical signal (color or fluorescence) or changes in optical properties such as absorption, reflectance, emission, etc. promoted by the biorecognition event. Lastly, piezoelectric transducers detect a mass increase induced by the antigen-antibody complex, which can be detectable by piezoelectric devices such as a quartz crystal balance or a microcantilever $[2,14]$.

Although there are many kinds of transducing mechanisms, this review is concerned with immunosensors whose transducing system is based on the field-effect transistors (FET). Such transducers are considered charge-sensitive devices and present several associated advantages such as excellent sensitivity and selectivity, label-free detection, real-time response, cost-effective fabrication, and ease of miniaturization and integration in electronic chips, making them excellent interfaces towards point-of-care (PoC) systems, as well as reusable and portable immunosensing devices. The focus of this review is the description of recent developments and current trends in FET-based immunosensors using nanomaterials as sensing platforms for different application fields. For a more thorough comprehension, we refer to several reviews on immunosensor principles [3,5,14], antibody engineering [4,6], transduction systems in immunosensing [5,14-16], basic mechanisms of FET sensors [17], and FET-based biosensors [18,19].

\section{FET-Based Immunosensors}

FET-based sensors have been exploited for decades since the first reports on ion-sensitive field effect transistors (ISFET) by Bergveld et al. [20-23]. FET-based biosensors operate by means of an electrical field modulating charge carriers across a semiconductor material. Such sensors are able to directly convert specific biological interactions into electrical signals. In the standard configuration of a FET, the electric current flows along a semiconductor channel connected to the source and drain electrodes. A third electrode, the gate contact, which is capacitively coupled to the device through a thin dielectric layer (typically $\mathrm{SiO}_{2}$ ), modulates the conductance between these two electrodes [20,24].

A FET-based sensor detects potential changes on its gate surface. The FET device characteristics can be assessed by the transfer curve, which is the plot of the current across drain-source electrodes $\left(\mathrm{I}_{\mathrm{DS}}\right)$ as a function of the gate voltage $\left(V_{G}\right)$ at a constant drain-source voltage $\left(V_{D S}\right)$ [25-27]. A FET-based biosensor usually operates in solution. In this case, the conductance between source and drain electrodes is modulated by a gate voltage applied in the electrolyte solution by means of a reference 
electrode placed on the top of the channel. In this configuration, the surface charge in an electrolyte attracts counter-ions forming the electric double layer (Debye layer) [26,28].

The semiconductor determines the type of charge carriers that can accumulate or deplete in the channel, thus the current flow can either be the result of movement of holes ("p-type") or electrons ("n-type"). For example, the application of positive voltage on the gate of a p-type channel FET results in depletion of charge carriers and a decrease in conductivity, whereas the application of negative voltage leads to accumulation of charge carriers and an increase in conductivity $[28,29]$. There is a great diversity of FET biosensors but we focus in this review on the FET-based immunosensors, whose concept was introduced by Shenck in 1978 [30]. In an immunoFET, which is shown schematically in Figure 1, the gate region is biofunctionalized by immobilizing antibodies or antigens on its surface, allowing direct analyte-binding upon the device surface. Since antibodies and antigens are mostly charged molecules, the biorecognition event imparts an electrical field, which modulates the charge carrier flow between source and gate, generating an electrically detectable signal [31,32]. Thus, the changes in conductance induced by the antigen-antibody binding can be measured and correlated to the analyte concentration [33].

ImmunoFET features simplicity of use and production, portability, high sensitivity (detecting picomolar and femtomolar levels of an analyte), utilizes a small volume of sample (in the microliters range), has low operating costs, and enables real-time analyte detection and quantification [34]. The exquisite sensibility of immunoFET is due to the fact that these sensors act as a combination of a sensor and an amplifier, in which the biorecognition channel is in direct contact with the analyte and the occurrence of only a single biological event is capable of causing a pronounced current change in the sensing channel $[35,36]$.

Under ideal conditions, an immunoFET is able to detect target biomolecules in biochemically or clinically meaningful range of concentrations, which can vary in the order of sub-fM to $\mu \mathrm{M}$, achieving very low detection limits. Ideal conditions include full antibody coverage, capacitive interface, highly charged antigens, and low ionic strength buffers [18]. However, in real conditions, samples contain rich levels of salts and species of non-interest. Therefore, these immunosensors present practical issues in transducing the antigen-antibody immunoreaction into a measurable signal and the direct sensing has proven to be challenging [37].

It was argued that an immunoFET is able to detect only charge or potential changes occurring within the Debye layer [21]. According to the Debye theory, an increase in ion concentration reduces the Debye length due to charge screening by counter-ions [38]. Thus, the Debye screening length, which is a physical distance where the charged analyte is electrically screened by the ions in the medium, strongly affects the immunosensor sensitivity in high ionic strength buffers. The Debye length $\left(\lambda_{D}\right)$ in an electrolyte is given by the following equation [39]:

$$
\lambda_{D}=\sqrt{\frac{\varepsilon_{0} \varepsilon_{r} k_{B} T}{2 N_{A} q^{2} I}},
$$

where $\varepsilon_{0}$ corresponds to the vacuum permittivity; $\varepsilon_{r}$ is the relative permittivity of the medium; $k_{B}$ is the Boltzmann constant; $T$ is the absolute temperature; $N_{A}$ is the Avogadro number; $q$ is the charge on an electron; and $I$ is the ionic strength of the solution.

Therefore, $\lambda_{D}$ is dependent on the ionic strength of the electrolytic buffer solution. To summarize, it decreases as the ionic strength increases, and a short Debye length implies a lower sensitivity because the FET sensor cannot detect the analyte-binding beyond the Debye length, as illustrated in Figure 2a. For instance, in a physiological solution (biological fluids such as blood, serum, urine, etc.) or undiluted phosphate-buffered saline solution (PBS buffer, ion concentration of $0.15 \mathrm{M}$ ), the dimensions of some antibodies (10-12 nm) are large enough to surpass the thickness of the Debye length $(\sim 0.8 \mathrm{~nm})$ at the electrolyte-immunosensor interface. In this case, the analyte charges will be at a farther distance from the surface than the Debye length and will be shielded from the sensing 
channel by buffer counter-ions $[17,40]$. However, the poor sensitivity caused by the enlargement of the Debye layer can be overcome by pretreating the analyte solution, which may include conditioning steps of centrifugation, filtration, and dilution to low ionic strength (ion concentration lower than $10^{-2}-10^{-3} \mathrm{M}$ ) prior to analysis [41], and then a measurable effect by an immunoFET can be observed.

(a)

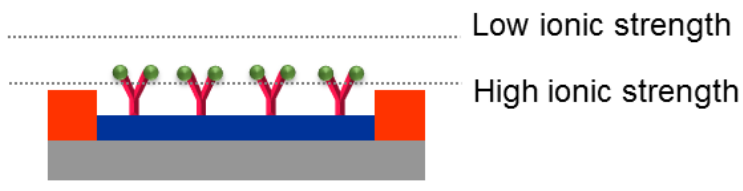

(b)

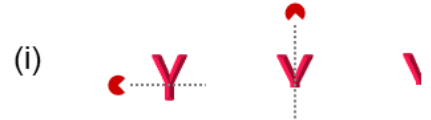

(ii)

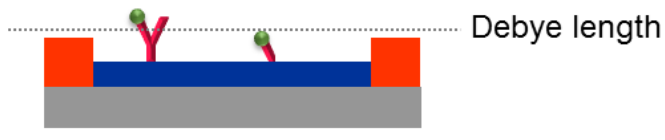

(c)

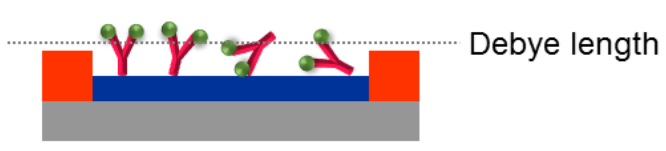

Figure 2. Antibodies ( $\mathrm{Y}$ shape) immobilized on the gate region. Antigens (spheres) are bound to antibodies and the dashed lines indicate the Debye length position. (a) The Debye length is dependent on the ionic strength of the electrolytic buffer and it increases with the reduction of solution ionic strength. A measurable analyte-binding may occur only within the Debye length; $(b, c)$ show alternative methods for antigen detection in high ionic strength solutions, without sample desalting; (b) (i) the antibody was cleaved by enzymatic digestion; and (ii) the antigen was brought within the Debye length [40]; (c) a more realistic representation of antibody alignment on the surface of an immunoFET showing random orientation of antibodies relative to the sensing surface, implying that some analyte-binding may occur within the Debye length [42].

The classical assessment described above evidences the dependence on proximity of the analyte to the device surface for an immunoFET proper function [19-23,43]. However, conceptual flaws concerning this model have been revised. In this context, Elnathan et al. demonstrated the direct detection of cardiac troponin I (cTnI) myocardial infarction biomarker without the need for sample desalting by bringing the antigen within the Debye length [40]. Their approach was based on fragmentation of antibody units, allowing the biorecognition event to occur in closer proximity to the silicon nanowire (SiNW) sensing surface, and consequently within the Debye screening length (Figure 2b). The authors cleaved antibodies by enzymatic digestion in order to remove parts that were not required for the antigen-binding and the fragments were able to directly detect cTnI with a sensitivity limit down to $\mathrm{pM}$, without the need of biosample desalting. Casal et al. discussed that antibodies were highly flexible structures that can adsorb to surfaces via a nearly random distribution of their structural domains, and can also be variably oriented in relation to the surface [42]. Therefore, the analytes can bind to antibodies in a distribution of orientations and distances from the sensing surface, implying that some analyte charges would be held within the Debye length, and consequently, the analyte should be detected by the immunoFET even in a high ionic strength condition (Figure 2c). The authors supported their assumption demonstrating multiple immunoFETs able to detect human and murine chemokines in physiologically relevant high ionic strength buffers [42]. 


\section{Trends in FET-Based Immunosensors Using Nanomaterials as Sensing Platforms}

Nanostructured materials have attracted a great deal of attention in their application for developing novel FET-based biosensing devices with enhanced sensibility and selectivity $[5,34,44]$. Owing to nanoscale dimensions (1-100 nm), nanomaterials exhibit tunable and unique physicochemical properties which are not observed in their bulk counterparts, including high specific surface area, high aspect ratio, increased chemical and thermal stability, and remarkable electrical properties. In addition, various biocompatible nanomaterials have their dimensions comparable to a range of biomolecules, facilitating their use for immunocompounds immobilization.

Nanomaterials are capable of modifying the exposed gate region of FET-based immunosensors, thus improving the immobilization of bioreceptors and the signal transducing [44]. Properties like the high aspect ratio allow the atoms to be located at or close to the gate surface, and as the biological recognition is related to the physical signal across the whole device, the device sensitivity is improved as a result of the increased surface-to-volume ratio. In addition, some nanomaterials can easily be chemically modified with specific sensing elements. Therefore, the use of nanomaterials as sensing platforms offers excellent interface perspectives for biological recognition, facilitating the attachment of biomolecules and allowing the scaling of microelectronics down to the nano level, which consequently enables the design of immunosensors with enhanced performance.

Recently, an increasing number of immunosensors using nanomaterials such as carbon nanotubes, graphene, nanowires, metal and metal oxide, and nanohybrids as semiconducting channel have been reported [44-46]. In this review, we highlight recent advances on the incorporation of nanomaterials on the gate surface of FET-based immunosensors applied to biomedical clinical diagnosis, environmental monitoring, and food safety fields. We consider the most important semiconducting nanomaterials for immunosensing purpose over the past five years. Selected reports outlining the exploitation of these nanomaterials in composing the sensing platform of FET immunosensors are discussed in the following sections.

Tables 1 and 2 assess the successful application of various types of nanomaterials in the fabrication of FET-based immunosensors. Recent reports were carefully examined on the basis of target analyte, electroactive nanomaterial, range of concentrations, and detection limit. Table 1 shows several FET immunosensors relevant to clinical biomedical diagnosis. It is evident that a great diversity of disease biomarkers can be detected through immunoFET devices, opening new paths for early-stage diagnosis of serious diseases such as cancer. For instance, prostate specific antigen (PSA), a prostate cancer biomarker, was ultrasensitively detected by using immunoFET devices based on different nanomaterials such as silicon nanowires (SiNW) [47,48], graphene [49], molybdenum disulfide $\left(\mathrm{MoS}_{2}\right)[50,51]$, etc. The lowest detection limit of PSA was achieved by a FET device based on SiNW $\left(1 \mathrm{fg} \cdot \mathrm{mL}^{-1}\right)$ [47]. Detection of tumor biomarkers for breast cancer [52,53], hepatic carcinoma [54], oral squamous cell carcinoma [55], pancreatic cancer [56], and bladder cancer [57] have also been reported. Moreover, other disease biomarkers related to cardiovascular diseases [58-60], thyroid hormone [61], venous thromboembolism [62], Alzheimer [63], and diabetes [64,65] have been detected with very low detection limits.

Table 2 evidences the ultrasensitive detection of pathogenic microorganisms associated with human health and food safety, such as Salmonella [66,67] and Escherichia coli [68-71] bacteria, rotavirus [72] and bacteriophage [69] viruses, and parasitic protozoan [73]. For example, graphene-based FET devices were found to detect only 10 colony-forming units per milliliter $\left(\mathrm{CFU} \cdot \mathrm{mL}^{-1}\right)$ of $E$. coli bacteria $[68,70]$ whereas a cerium oxide $\left(\mathrm{CeO}_{\mathrm{x}}\right)$-based FET device was able to achieve a limit of detection (LOD) as low as 2-3 cells of Salmonella typhimurium per mL [67]. Table 2 also depicts the application of immunoFET devices for detecting environmental contaminants such as pesticides [74], herbicides [75], toxins [76], and phytopathogens [77]. 
Table 1. Recent reports on immunoFET sensors based on various types of nanomaterials applied to clinical biomedical diagnosis.

\begin{tabular}{|c|c|c|c|c|}
\hline Target Analyte & Electroactive Nanomaterial & Range & Detection Limit & Reference \\
\hline -H5N2 avian influenza virus & SiNW & $10^{-17}-10^{-12} \mathrm{M}$ & $10^{-17} \mathrm{M}$ & [78] \\
\hline Hepatitis B marker (HBsAg) and cancer marker $\alpha$-fetoprotein (AFP) & SiNW & - & $\begin{array}{l}10^{-14} \mathrm{M} \text { for HBsAg and } 10^{-15} \mathrm{M} \\
\text { for AFP }\end{array}$ & [79] \\
\hline Human thyroid stimulating hormone & SiNW & $0.02-30 \mathrm{mIU} \cdot \mathrm{L}^{-1}$ & $0.02 \mathrm{mIU} \cdot \mathrm{L}^{-1}$ & [61] \\
\hline $\begin{array}{l}\text { Biomarkers of oral squamous cell carcinoma Interleukin-8 (IL-8) and } \\
\text { tumor necrosis factor } \alpha \text { (TNF- } \alpha \text { ) }\end{array}$ & SiNW & $1 \mathrm{fg} \cdot \mathrm{mL}^{-1}-1 \mathrm{ng} \cdot \mathrm{mL}^{-1}$ & $\begin{array}{l}10 \mathrm{fg} \cdot \mathrm{mL}-1 \text { in PBS and } \\
100 \mathrm{fg} \cdot \mathrm{mL}^{-1} \text { in saliva }\end{array}$ & [55] \\
\hline $\begin{array}{l}\text { Cancer biomarkers cytokeratin } 19 \text { fragment (CYFRA21-1) and } \\
\text { prostate specific antigen (PSA) }\end{array}$ & SiNW & $1 \mathrm{fg} \cdot \mathrm{mL}^{-1}-1 \mathrm{ng} \cdot \mathrm{mL}^{-1}$ & $\begin{array}{c}1 \mathrm{fg} \cdot \mathrm{mL}^{-1} \text { in buffer solution and } \\
10 \mathrm{fg} \cdot \mathrm{mL}^{-1} \text { in undiluted } \\
\text { human serums }\end{array}$ & [47] \\
\hline Prostate cancer biomarker PSA & SiNW & $5 \mathrm{fg} \cdot \mathrm{mL}^{-1}-500 \mathrm{pg} \cdot \mathrm{mL}^{-1}$ & $\begin{array}{l}5 \mathrm{fg} \cdot \mathrm{mL}^{-1} \text { in buffer and } \\
\text { desalted serum }\end{array}$ & [48] \\
\hline $\begin{array}{l}\text { AFP and carcinoembryonic antigen (CEA) primary hepatic } \\
\text { carcinoma biomarkers }\end{array}$ & SiNW & $\begin{array}{l}500 \mathrm{fg} \cdot \mathrm{mL}^{-1}-50 \mathrm{ng} \cdot \mathrm{mL}^{-1} \text { for AFP and } \\
50 \mathrm{fg} \cdot \mathrm{mL}^{-1}-10 \mathrm{ng} \cdot \mathrm{mL}^{-1} \text { for CEA }\end{array}$ & $\begin{array}{l}500 \mathrm{fg} \cdot \mathrm{mL}^{-1} \text { for AFP and } \\
50 \mathrm{fg} \cdot \mathrm{mL}^{-1} \text { for CEA }\end{array}$ & [54] \\
\hline Cardiac troponin I (cTnI) biomarker for acute myocardial infarction & SiNW & $0.092 \mathrm{ng} \cdot \mathrm{mL}^{-1}-46 \mathrm{ng} \cdot \mathrm{mL}^{-1}$ & $0.092 \mathrm{ng} \cdot \mathrm{mL}^{-1}$ & [60] \\
\hline Cardiac disease biomarker cTnI & SiNW & $5 \mathrm{pg} \cdot \mathrm{mL}^{-1}-5 \mathrm{ng} \cdot \mathrm{mL}^{-1}$ & $5 \mathrm{pg} \cdot \mathrm{mL}^{-1}$ & [59] \\
\hline $\begin{array}{l}\text { C-reactive protein (CRP) inflammatory biomarker related with } \\
\text { cardiovascular diseases }\end{array}$ & SWCNT & $10^{-4}$ to $10^{2} \mu \mathrm{g} \cdot \mathrm{mL}^{-1}$ & $10^{-4} \mu \mathrm{g} \cdot \mathrm{mL}^{-1}$ & [58] \\
\hline Prostate cancer biomarker osteopontin (OPN) & SWCNT & $1 \mathrm{pg} \cdot \mathrm{mL}^{-1}-1 \mu \mathrm{g} \cdot \mathrm{mL}^{-1}$ & $0.3 \mathrm{pg} \cdot \mathrm{mL}^{-1}$ & [80] \\
\hline $\begin{array}{l}\text { Pro-inflammatory cytokine and anti-inflammatory myokine } \\
\text { interleukin-6 (IL-6) }\end{array}$ & SWCNT & $1 \mathrm{pg} \cdot \mathrm{mL}^{-1}-100 \mathrm{pg} \cdot \mathrm{mL}^{-1}$ & $1.37 \mathrm{pg} \cdot \mathrm{mL}^{-1}$ & [81] \\
\hline Stress biomarker cortisol in saliva & SWCNT & $1 \mathrm{pg} \cdot \mathrm{mL}^{-1}-1000 \mathrm{ng} \cdot \mathrm{mL}^{-1}$ & $1 \mathrm{pg} \cdot \mathrm{mL}^{-1}$ & [82] \\
\hline Lyme disease antigen & SWCNT & $1 \mathrm{ng} \cdot \mathrm{mL}^{-1}-3000 \mathrm{ng} \cdot \mathrm{mL}^{-1}$ & $1 \mathrm{ng} \cdot \mathrm{mL}^{-1}$ & [83] \\
\hline Prostate cancer biomarker OPN & SWCNT & $1 \mathrm{pg} \cdot \mathrm{mL}^{-1}-1 \mu \mathrm{g} \cdot \mathrm{mL}^{-1}$ & $1 \mathrm{pg} \cdot \mathrm{mL}^{-1}$ or $30 \mathrm{fM}$ & [84] \\
\hline Alzheimer biomarker, amyloid- $\beta$ & SWCNT & $10^{-12}-10^{-9} \mathrm{~g} \cdot \mathrm{mL}^{-1}$ & $1 \mathrm{pg} \cdot \mathrm{mL}^{-1}$ in human serum & [63] \\
\hline Chondroitin sulfate proteoglycan 4 , multiple cancer types biomarker & Graphene & $0.01 \mathrm{fM}-10 \mathrm{pM}$ & $0.01 \mathrm{fM}$ & [85] \\
\hline Pancreatic cancer biomarker, carbohydrate antigen 19-9 (CA 19-9) & Graphene & 0.01 unit $\cdot \mathrm{mL}^{-1}-1000$ unit $\cdot \mathrm{mL}^{-1}$ & 0.01 unit $\cdot \mathrm{mL}^{-1}$ & [56] \\
\hline Prostate specific antigen $/ \alpha 1$-antichymotrypsin (PSA-ACT) complex & Graphene & $100 \mathrm{fg} \cdot \mathrm{mL}^{-1}-1 \mu \mathrm{g} \cdot \mathrm{mL}^{-1}$ & $100 \mathrm{fg} \cdot \mathrm{mL}^{-1}$ & [49] \\
\hline $\begin{array}{l}\text { Breast cancer biomarkers human epidermal growth factor receptor } 2 \\
\text { (HER2) and epidermal growth factor receptor (EGFR) }\end{array}$ & $\mathrm{SiO}_{2} /$ graphene & $100 \mathrm{pM}-1 \mu \mathrm{M}$ & $\begin{array}{l}1 \mathrm{pM} \text { for HER2 and } 100 \mathrm{pM} \\
\text { for EGFR }\end{array}$ & [52] \\
\hline Human immunodeficiency virus (HIV) & Graphene/CPPyNP & $1 \mathrm{pM}-10 \mathrm{nM}$ & $1 \mathrm{pM}$ & [86] \\
\hline Bladder cancer biomarker, urinary APOA2 protein & Graphene/SiNW & $19.5 \mathrm{pg} \cdot \mathrm{mL}^{-1}-1.95 \mathrm{mg} \cdot \mathrm{mL}^{-1}$ & $6.7 \mathrm{pg} \cdot \mathrm{mL}^{-1}$ & [57] \\
\hline Prostate cancer biomarker PSA-ACT complex & Graphene/ZnO nanorods/ $\mathrm{TiO}_{2}$ & $100 \mathrm{fg} \cdot \mathrm{mL}^{-1}-100 \mathrm{ng} \cdot \mathrm{mL}^{-1}$ & $1 \mathrm{fM}$ & [87] \\
\hline D-Dimer, biomarker of venous thromboembolism & Graphene $/ \mathrm{TiO}_{2}$ & $10 \mathrm{pg} \cdot \mathrm{mL}^{-1}-100 \mathrm{ng} \cdot \mathrm{mL}^{-1}$ & $\begin{array}{l}10 \mathrm{pg} \cdot \mathrm{mL}^{-1} \text { in buffer and } \\
100 \mathrm{pg} \cdot \mathrm{mL}^{-1} \text { in serum sample }\end{array}$ & [62] \\
\hline
\end{tabular}


Table 1. Cont.

\begin{tabular}{|c|c|c|c|c|}
\hline Target Analyte & Electroactive Nanomaterial & Range & Detection Limit & Reference \\
\hline Prostate cancer biomarker PSA & $\mathrm{MoS}_{2}$ & $3.75 \mathrm{nM}, 37.5 \mathrm{pM}$, and $375 \mathrm{fM}$ & $375 \mathrm{fM}$ & [51] \\
\hline Prostate cancer biomarker PSA & $\mathrm{MoS}_{2}$ & $1 \mathrm{pg} \cdot \mathrm{mL}^{-1}-10 \mathrm{ng} \cdot \mathrm{mL}^{-1}$ & $1 \mathrm{pg} \cdot \mathrm{mL}^{-1}$ & [50] \\
\hline Breast cancer biomarker EGFR & ZnO nanofilm & $10 \mathrm{fM}-10 \mathrm{nM}$ & $10 \mathrm{fM}$ & [53] \\
\hline Prostate cancer biomarker PSA & Si nanobelt & $50 \mathrm{fg} \cdot \mathrm{mL}^{-1}-500 \mathrm{pg} \cdot \mathrm{mL}^{-1}$ & $5 \mathrm{pg} \cdot \mathrm{mL}^{-1}$ & [88] \\
\hline Index for diabetes, Hemoglobin-A1c & Au nanoparticles & $1.67 \mathrm{ng} \cdot \mathrm{mL}^{-1}-170.5 \mathrm{ng} \cdot \mathrm{mL}^{-1}$ & in the order of $\mathrm{ng} \cdot \mathrm{mL}^{-1}$ & [65] \\
\hline Diabetes related hormone, insulin & Si nanogratings & $1 \mathrm{fM}-1 \mathrm{nM}$ & $\begin{array}{c}10 \mathrm{fM} \text { in buffer and diluted } \\
\text { human serum }\end{array}$ & [64] \\
\hline CRP inflammatory biomarker & P3HT polymer & $4 \mathrm{pM}-2 \mu \mathrm{M}$ & $2 \mathrm{pM}$ & [89] \\
\hline
\end{tabular}

Table 2. Recent reports on immunoFET sensors based on various types of nanomaterials listed along with their application in food safety and environmental monitoring fields.

\begin{tabular}{|c|c|c|c|c|}
\hline Target Analyte & Electroactive Nanomaterial & Range & Detection Limit & Reference \\
\hline \multicolumn{5}{|l|}{ Food safety } \\
\hline Salmonella bacteria & SWCNT & $10^{3}-10^{8} \mathrm{CFU} \cdot \mathrm{mL}^{-1}$ & $10^{3} \mathrm{CFU} \cdot \mathrm{mL}^{-1}$ & [66] \\
\hline Escherichia coli foodborne pathogen & SWCNT & $10^{2}-10^{5} \mathrm{CFU} \cdot \mathrm{mL}^{-1}$ & $10^{2} \mathrm{CFU} \cdot \mathrm{mL}^{-1}$ & [71] \\
\hline Escherichia coli $\mathrm{O} 157: \mathrm{H} 7$ and bacteriophage viruses & SWCNT & $\begin{array}{c}10^{3}-10^{7} \mathrm{CFU} \cdot \mathrm{mL}^{-1} \text { for } E \text {. coli and } \\
10^{2}-10^{7} \mathrm{PFU} \cdot \mathrm{mL}^{-1} \text { for bacteriophage }\end{array}$ & $\begin{array}{c}10^{5} \mathrm{CFU} \cdot \mathrm{mL}^{-1} \text { for } E \text {. coli and } \\
10^{3} \mathrm{PFU} \cdot \mathrm{mL}^{-1} \text { for bacteriophage }\end{array}$ & [69] \\
\hline Cryptosporidium parvum intestinal parasitic protozoan & Graphene & $10^{2}-10^{4} \mathrm{Cp}$. oocysts per $4 \mathrm{~mL}$ buffer & 25 Cp. oocysts per $\mathrm{mL}$ buffer & [73] \\
\hline Escherichia coli bacteria & Graphene & $10-10^{5} \mathrm{CFU} \cdot \mathrm{mL}^{-1}$ & $10 \mathrm{CFU} \cdot \mathrm{mL}^{-1}$ & [70] \\
\hline Escherichia coli O157:H7 bacteria & Graphene & $10-10^{4} \mathrm{CFU} \cdot \mathrm{mL}^{-1}$ & $10 \mathrm{CFU} \cdot \mathrm{mL}^{-1}$ & [68] \\
\hline Food toxin aflatoxin B1 & Graphene & $10^{-4} \mathrm{ppt}^{-1} \cdot \mathrm{ppt}$ & $0.1 \mathrm{fg} \cdot \mathrm{mL}^{-1}$ & [90] \\
\hline Rotavirus & Graphene & $0-10^{5} \mathrm{PFU} \cdot \mathrm{mL}^{-1}$ & $10^{2} \mathrm{PFU} \cdot \mathrm{mL}^{-1}$ & [72] \\
\hline Salmonella typhimurium bacteria & $\mathrm{CeO}_{\mathrm{x}}$ & $2-5 \times 10^{5}$ cells $\cdot \mathrm{mL}^{-1}$ & $2-3$ cells $\cdot \mathrm{mL}^{-1}$ & [67] \\
\hline \multicolumn{5}{|l|}{ Environmental monitoring } \\
\hline Atrazine pesticide & SWCNT & $0.001-10 \mathrm{ng} \cdot \mathrm{mL}^{-1}$ & $0.001 \mathrm{ng} \cdot \mathrm{mL}^{-1}$ & [74] \\
\hline 2,4-Dichlorophenoxyacetic acid herbicides & SWCNT & $5 \mathrm{fM}-500 \mu \mathrm{M}$ & $\begin{array}{l}500 \mathrm{fM} \text { in soil sample and } \\
50 \mathrm{pM} \text { in buffer }\end{array}$ & [75] \\
\hline 2,4,6-Trinitrotoluene (TNT) contamination & SWCNT & $0.5 \mathrm{ppb}-5000 \mathrm{ppb}$ & $0.5 \mathrm{ppb}$ & [76] \\
\hline Microcystin-LR (cyanotoxin in surface waters) & SWCNT & $1-1000 \mathrm{ng} \cdot \mathrm{L}^{-1}$ & $0.6 \mathrm{ng} \cdot \mathrm{L}^{-1}$ & [91] \\
\hline Citrus tristeza virus and Xylella fastidiosa phytopathogens & $\operatorname{InP}$ & $\begin{array}{l}\text { 60-340 ng.mL } \mathrm{mL}^{-1} \text { for Citrus tristeza virus } \\
\text { and } 34-250 \mathrm{ng} \cdot \mathrm{mL}^{-1} \text { for Xylella fastidiosa }\end{array}$ & $2 \mathrm{nM}$ for both phytopathogens & [77] \\
\hline
\end{tabular}




\subsection{Silicon Nanowires}

Silicon nanowires (SiNW) are semiconducting one-dimensional (1D) nanostructures with cross-sectional diameters of nanometers and length of micrometers, which can exhibit either p-type or n-type conductivity [92-94]. SiNW are attractive materials in FET-based biosensors design due to their high surface-to-volume ratio, which enables the sensors ultrasensitive detection capability $[95,96]$. SiNW FET-based biosensors were firstly reported in 2011 by Cui et al. [97]. The authors demonstrated that p-type boron-doped SiNW modified with biotin detected streptavidin protein down to picomolar concentration range.

FET biosensors based on SiNW have been employed as promising clinical diagnostic platforms. For example, Huang et al. developed a novel SiNW-FET biosensor for the detection of PSA biomarker in human serum [48]. The SiNW were fabricated by the polysilicon sidewall spacer technique, which is cheaper than the electron beam lithography. Figure 3a depicts top-view scanning electron microscopy (SEM) images of such SiNW-FET devices. The SiNW surface was modified with 3-aminopropyltriethoxysilane (APTES) to convert silanol groups into amines for glutaraldehyde functionalization. Then, the aldehyde groups present on glutaraldehyde molecules were connected to the amine groups to form the linker between APTES and anti-PSA antibodies. The transfer curve of such n-type SiNW-FET sensor showed that the drain-source current $\left(\mathrm{I}_{\mathrm{DS}}\right)$ was controlled by the gate voltage $\left(\mathrm{V}_{\mathrm{G}}\right)$ (Figure $\left.3 \mathrm{~b}\right)$. The device exhibited excellent electrical performance, and the $\mathrm{I}_{\mathrm{DS}}$ versus drain-source voltage $\left(\mathrm{V}_{\mathrm{DS}}\right.$ ) depended on the applied $\mathrm{V}_{\mathrm{G}}$ (Figure 3c). Human serum was pretreated by filtration, desalting, and buffer exchange prior to PSA detection in order to keep proper $\mathrm{pH}$ and ionic strength of serum proteome. The electrical responses from the measurement of various PSA concentrations in desalted human serum are shown in Figure $3 \mathrm{~d}$ and the immunosensor was able to detect PSA levels in concentrations as low as $5 \mathrm{fg} \cdot \mathrm{mL}^{-1}$.

Alpha-fetoprotein (AFP) and carcinoembryonic antigen (CEA) markers high expression levels have been associated with primary hepatic carcinoma (PHC). In this context, Zhu et al. developed SiNW-FET with polydimethylsiloxane (PDMS) microfluidic channels for the simultaneous detection of both AFP and CEA biomarkers in desalted human serum [54]. SiNW surface was treated with APTES and glutaraldehyde before the AFP and CEA antibodies immobilization by covalent bonding. Bovine serum albumin (BSA) was used as a blocking agent for non-specific binding. The negatively charged AFP and CEA enhanced the conductivity of the p-type SiNW. The dual-channel setup demonstrated the potential use of SiNW-FET for multiple tumor markers detection in concentrations down to fg. $\mathrm{mL}^{-1}$ and $\mathrm{ng} \cdot \mathrm{mL}^{-1}$.

Cardiac troponin I, a very sensitive biomarker for acute myocardial infarction, was detected by a label-free SiNW-FET biosensor [60]. Anti-cTnI antibodies were immobilized on the SiNW surfaces for measuring the cTnI in a range of concentrations from $0.092 \mathrm{ng} \cdot \mathrm{mL}^{-1}$ to $46 \mathrm{ng} \cdot \mathrm{mL}^{-1}$. Higher sensitivity of cTnI detection was reported by Kim et al. [59]. The authors demonstrated a SiNW honeycomb-like structure for nanowire configuration. The geometry of honeycomb nanowires provided increased surface area rather than straight nanowire configuration, improving the probability of binding events between antigen and antibody, and enabling superior intrinsic electrical performance of biosensors. The devices showed n-type behavior and presented LOD of $5 \mathrm{pg} \cdot \mathrm{mL}^{-1}$, which was about 8-fold smaller than the value previously reported by Kong et al. [60].

As aforementioned, the detection mechanism of FET-based biosensors is hampered in samples of high ionic strength and efforts for bringing the antigen-antibody binding within the Debye layer have been reported [40]. Puppo et al. got rid of the Debye screening problem by performing the electrical measurements on dried samples after the antigen-binding coupling [98]. The authors developed a SiNW-FET sensor for the detection of vascular endothelial growth factor (VEGF), a pathological angiogenesis factor. Increasing concentrations of VEGF caused increase in conductance, leading to detection in the concentration range of $\mathrm{fM}$. 
(a)
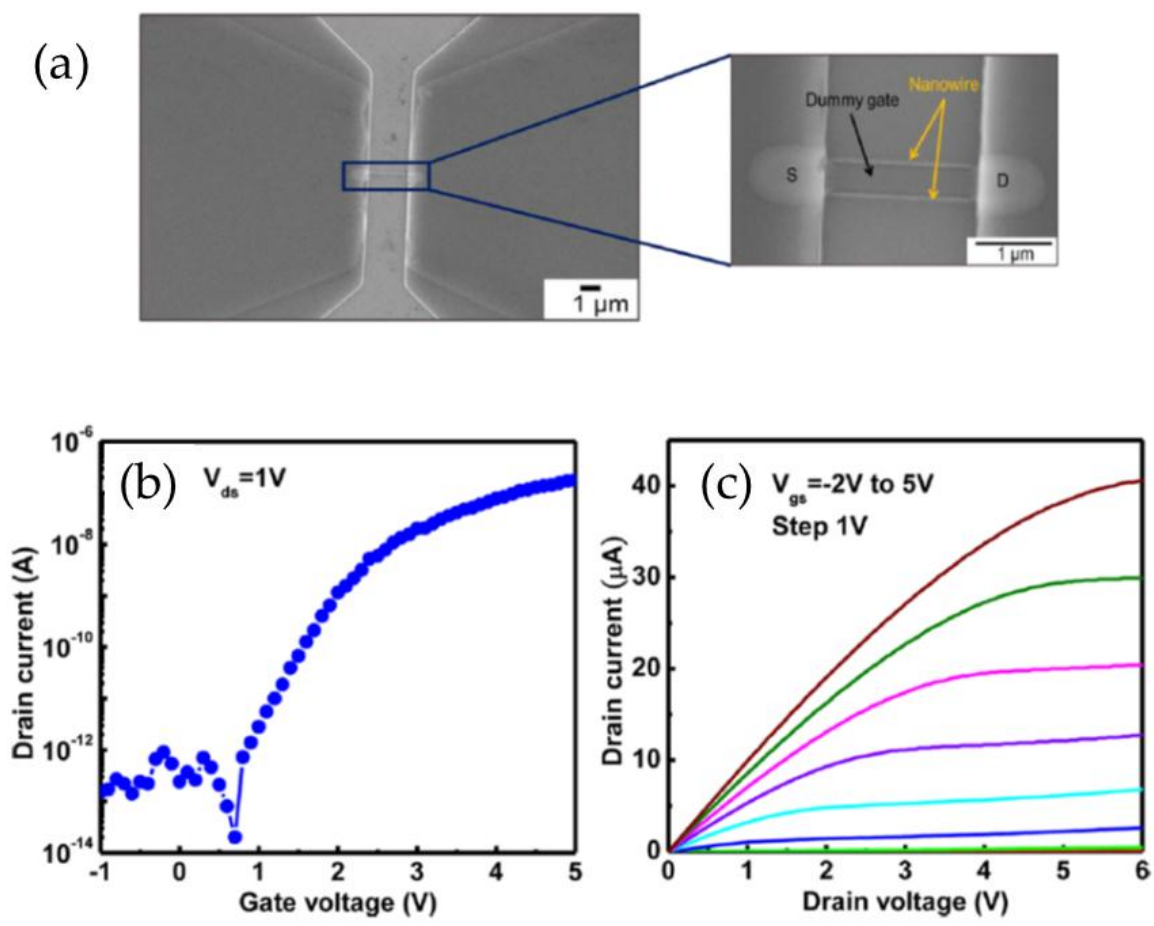

(d)

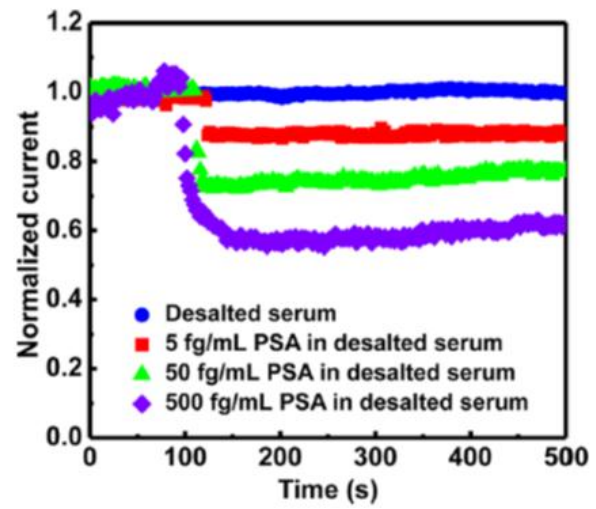

Figure 3. n-type SiNW-based FET immunosensor for detection of PSA biomarker. (a) SEM images of a SiNW-FET sensor; (b) Electrical characteristics ( $\mathrm{I}_{\mathrm{DS}} \times \mathrm{V}_{\mathrm{G}}$ curves) of the SiNW-FET device; (c) Output characteristics ( $\mathrm{I}_{\mathrm{DS}} \times \mathrm{V}_{\mathrm{DS}}$ curves) showing a dependence on the controlled $\mathrm{V}_{\mathrm{G}} ;(\mathbf{d})$ Normalized current $\times$ time for SiNW devices to detect various PSA concentrations in desalted human serum. No electrical response was observed for serum without PSA. Reprinted with permission from Huang et al. [48]. Copyright 2016 American Chemical Society.

\subsection{Carbon Nanotubes}

Carbon nanotubes are cylindrical carbon structures with diameters of nanometers and high length/diameter ratio [99]. Multi-walled carbon nanotubes (MWCNT) consist of multiple rolled graphite sheets [100] while single-walled carbon nanotubes (SWCNT) are single-atom rolled graphitic layers [101,102]. Carbon nanotubes are exciting 1D materials due to their structure-dependent electronic and mechanical properties. Their physical properties are strongly dependent on the way that graphitic sheets are wrapped to form the tubes (chirality), causing them to exhibit metallic or semiconducting characteristics [99]. In particular, SWCNTs have been explored as promising building blocks in the construction of FET-based immunosensors with improved sensibility [58,69,76,80-82,103]. SWCNTs display high electron transfer because all carbon atoms are present in their surface. 
In addition, SWCNTs surface can be easily modified, giving various possibilities for non-covalent and covalent immobilization of antigens or antibodies.

For instance, Justino et al. reported an immunoFET based on SWCNT functionalized with C-reactive protein (CRP) antibodies for detecting CRP, an inflammatory biomarker related with cardiovascular diseases [58]. The anti-CRP antibodies were non-covalently immobilized directly on the surface of SWCNT and the devices were capable of detecting CRP in the broad range of concentrations from $10^{-4}$ to $10^{2} \mu \mathrm{g} \cdot \mathrm{mL}^{-1}$. In addition, the LOD of such devices $\left(10^{-4} \mu \mathrm{g} \cdot \mathrm{mL}^{-1}\right)$ was 2-3 orders lower than conventional immunoassays. Sharma et al. reported a SWCNT-FET sensor for detecting the prostate cancer biomarker osteopontin (OPN) [80]. SWCNTs were deposited on transparent glass substrates by dielectrophoresis, allowing the direct alignment of the nanotubes at room temperature. The SWCNT surface was treated with 1-ethyl-3-(3-dimethylaminopropyl) carbodiimide (EDC)/ $N$-hydroxysuccinimide (NHS). Then, the covalent immobilization of monoclonal antibodies specific for OPN occurred through the binding with $\mathrm{NH}_{2}$ groups of NHS succinimide ester on the SWCNTs. These devices were incubated with Tween 20 to avoid non-specific binding. The electrical measurements showed a linear behavior after each step of functionalization of the SWCNT-FET device, indicating a good ohmic contact between SWCNTs and source/drain electrodes. Immunosensors exhibited a highly linear resistance change over a range of concentrations $\left(1 \mathrm{pg} \cdot \mathrm{mL}^{-1}\right.$ to $1 \mu \mathrm{g} \cdot \mathrm{mL}^{-1}$ ) of the prostate cancer biomarker OPN in human serum and PBS buffer, being 3-fold more sensitive than the conventional ELISA immunoassay, with a LOD of $0.3 \mathrm{pg} \cdot \mathrm{mL}^{-1}$.

Horizontally aligned SWCNTs grown on quartz substrates were applied as sensing platform for measuring interleukin-6 (IL-6), a protein that acts as pro-inflammatory cytokine and anti-inflammatory myokine [81]. The highly specific binding of the IL-6 analyte to the antibodies in the gate region caused a change in the drain current, which was measured as an electrical signal. The devices exhibited low detection limit (1.37 $\left.\mathrm{pg} \cdot \mathrm{mL}^{-1}\right)$, good selectivity (no responses for BSA and cysteine), and excellent stability (no electronic degradation after storage for up to three months).

Carbon nanotubes-based FET immunosensors are also able to detect microorganisms such as bacteria and viruses. García-Aljaro et al. reported an immunoFET based on SWCNT for the detection of human pathogens Escherichia coli O157:H7 bacteria and bacteriophage T7 viruses [69]. The sensing platform was composed of parallel aligned SWCNTs functionalized with 1-pyrene butanoic acid succinimidyl ester (PBASE), in which monoclonal antibodies were covalently attached. The immunosensor exhibited a linear response for both bacteria and viruses increasing concentrations, achieving LOD of $10^{5}$ colony forming units per milliliters (CFU $\mathrm{mL}^{-1}$ ) and $10^{3}$ plaque forming units per milliliter (PFU. $\mathrm{mL}^{-1}$ ), respectively. The biosensor showed a better performance for bacteriophage. This result can be attributed to the decreased size and different morphology of such viruses in comparison to bacteria, which enabled a better and faster diffusion of bacteriophage in the solution towards the antibodies.

Small molecules, either charged or uncharged, cannot be detected by the conventional configuration of an immunoFET, where the biorecognition event between the analyte and the immobilized molecules takes place at the gate sensing surface. In this case, the analyte binding does not produce a measurable conductance change because of the lack of charge or depletion in the semiconductor channel [103]. Therefore, the displacement represents a successful strategy for detecting such target analytes. For example, Tliti et al. described a label-free FET immunosensor based on SWCNT for the ultrasensitive detection of stress biomarker cortisol in saliva [82]. SWCNTs were covalently functionalized with a cortisol analog (cortisol-3-CMO-NHS ester) followed by covalent conjugation with monoclonal anti-cortisol antibodies (large size and charged proteins). This chemiresistive biosensor was able to detect small size and uncharged cortisol molecules because the antibody bound to the SWCNT functionalized with cortisol analog was stripped/displaced, provoking a large change of the device resistance/conductance and a LOD of $1 \mathrm{pg} \cdot \mathrm{mL}^{-1}$ [82]. Tan et al. also fabricated a label-free immunoFET based on SWCNT by the displacement assay of the immobilized antibodies [91]. The immunosensors were able to detect the small molecular mass 
microcystin-LR (MCRL), a toxin released by cyanobacteria in surface waters, with high sensitivity and specificity along with a detection limit of $0.6 \mathrm{ng} \cdot \mathrm{L}^{-1}$. Park and co-workers applied a SWCNT immunoFET for the detection of a small molecule of 2,4,6-trinitrotoluene (TNT), a compound used as ammunition/explosive [76]. It is a harmful chemical to soil and groundwater and can cause severe environmental contaminations. The authors also employed the displacement mode/format to develop the SWCNT-based immunosensor. The biosensor detected TNT with good selectivity and LOD of $0.5 \mathrm{ppb}$.

\subsection{Graphene}

Graphene consists of a honeycomb lattice of carbon atoms arranged in a two-dimensional (2D) array in which atoms are covalently linked through $\mathrm{sp}^{2}$ hybridization. Actually, graphene is the building block of different carbon allotropes: single layer sheets can be enrolled in carbon nanotubes, wrapped in fullerenes, and stacked in three-dimensional graphite [104,105]. Graphene has attracted much attention because of its remarkable properties, including high surface area $\left(\sim 2630 \mathrm{~m}^{2} \cdot \mathrm{g}^{-1}\right)$, carrier mobility $\left(\sim 200,000 \mathrm{~cm}^{2} \cdot \mathrm{V}^{-1} \cdot \mathrm{s}^{-1}\right)$, electrical conductivity $\left(\sim 10^{4} \mathrm{~S} \cdot \mathrm{cm}^{-1}\right)$, optical transmittance, and Young's modulus of $\sim 1 \mathrm{TPa}$ [106-108]. Its notable electronic and optical properties are due to electron confinement and absence of interlayer interactions, whereas its distinct mechanical and chemical properties are explained by geometrical effects and high surface-to-volume ratio [109]. These exceptional set of properties are particularly useful for the development of electronic sensors with high signal-to-noise ratio. Moreover, graphene is a zero bandgap semiconductor and shows ambipolar field-effect when incorporated in the configuration of a FET, since the Fermi level can be modulated by the application of a voltage between graphene and the transistor source [110-112].

This 2D nanomaterial presents some advantages beyond other nanostructures in FET-based sensors design. For example, graphene exhibits high specific surface area that can be easily functionalized for specific interactions, and providing an increased contact area for detection. Graphene is biocompatible, which helps to maintain the activity of antibodies; has excellent conductivity, which enhances the electron transfer at the electrode surface, improving the sensibility; and exhibits ambipolar characteristics [105], being able to detect both positive and negatively charged biomolecules. Additionally, as each carbon atom of the 2D structure is directly exposed to the environment, any biological recognition event occurring at the gate surface will generate an electrical perturbation in the surrounding, thus improving the sensibility of the biosensor [113].

Graphene has been employed as sensing platform of FET immunosensors for detecting various disease biomarkers. For example, Jung et al. developed a graphene FET sensor for detecting a pancreatic cancer biomarker, carbohydrate antigen 19-9 (CA 19-9). Graphene was grown by chemical vapor deposition (CVD) technique and transferred by a novel method to the sensor substrate, free from remaining polymer residues. The cleaner surface resulted in higher p-doping, higher channel mobility, and significantly enhanced sensitivity [56]. Prostate cancer biomarker, PSA / $\alpha$-1-antichymotrypsin (PSA-ACT) complex, was detected by a FET sensor based on reduced graphene oxide (RGO), a chemically derived graphene [49]. RGO nanosheets were self-assembled on an aminated substrate and monoclonal PSA antibodies were immobilized on this channel. Immunoreactions caused a linear shift of gate voltage, with a LOD as low as $100 \mathrm{fg} \cdot \mathrm{mL}^{-1}$.

Graphene-based FET sensors are also capable of detecting foodborne and waterborne pathogens such as bacteria. Huang et al. demonstrated an immunosensor based on CVD graphene to detect E. coli bacteria [70]. Graphene was deposited on a quartz substrate. Anti-E. coli antibodies were immobilized on the graphene surface through a linker molecule (PBASE), which provided an ester group to react with amino groups of antibodies. Non-specific binding was prevented by ethanolamine and Tween 20 was used to passivate the uncoated regions of graphene (Figure $4 \mathrm{a}$ ). Figure $4 \mathrm{~b}$ exhibits the transfer curves of the graphene-based FET sensor after each functionalization step, demonstrating the ambipolar characteristics of graphene. Such a biosensor operating at the p-type region exhibited a significant conductance increase after exposure to various E. coli concentrations (from 
0 to $10^{5} \mathrm{CFU} \cdot \mathrm{mL}^{-1}$ ) (Figure $4 \mathrm{c}$ ). No response was triggered after exposure to Pseudomonas aeruginosa bacteria, indicating high specificity (Figure $4 \mathrm{~d}$ ).

(a)

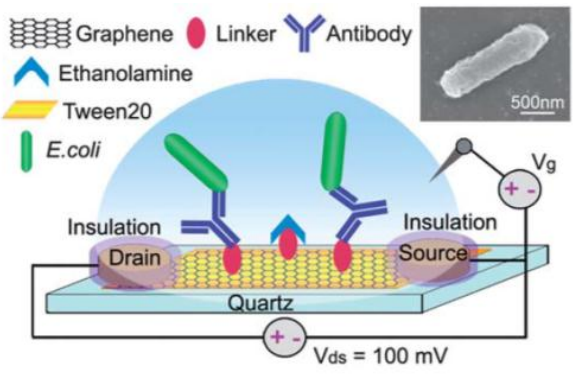

(c)

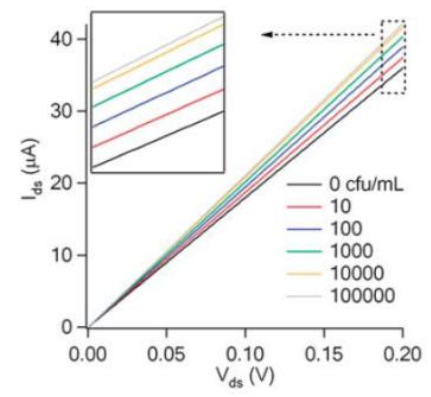

(b)

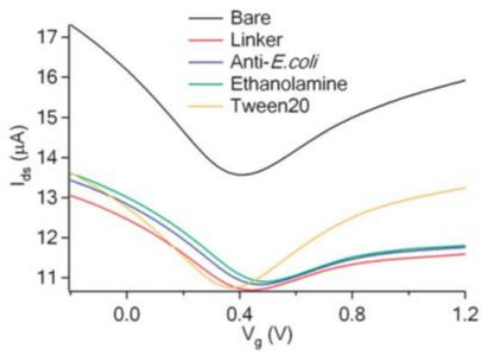

(d)

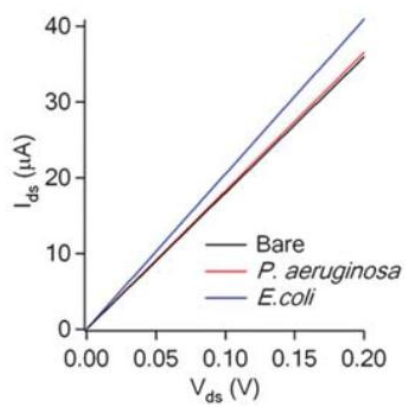

Figure 4. (a) Scheme showing a graphene-based FET sensor operating in an electrolyte solution for detecting E. coli bacteria. Bacterial cells were attached to antibodies immobilized onto the graphene surface; (b) Transfer curves $\left(\mathrm{I}_{\mathrm{DS}} \times \mathrm{V}_{\mathrm{G}}\right.$ ) of the graphene-FET sensor. Graphene exhibited ambipolar characteristics; (c) $\mathrm{I}_{\mathrm{DS}} \times \mathrm{V}_{\mathrm{DS}}$ curves of graphene FET devices on various E. coli concentrations; (d) $\mathrm{I}_{\mathrm{DS}}$ $\times \mathrm{V}_{\mathrm{DS}}$ characteristics of devices after incubation with . aeruginosa, demonstrating high specificity of detection. Reproduced from Huang et al. [70] with permission from The Royal Society of Chemistry.

Chang et al. reported a graphene-based FET device to detect the most pathogenic strain of E. coli bacteria, known as E. coli O157:H7 [68]. The authors fabricated FET devices by a solution process in which graphene oxide nanosheets were self-assembled on the substrate and subsequently reduced by thermal annealing. The conductance of the devices increased with increasing concentrations of $E$. coli cells, achieving a detection limit as low as $10 \mathrm{CFU} \cdot \mathrm{mL}^{-1}$. Such a device operated in the p-type region and the conductance increase was induced by the highly negatively charged bacterial cells. Pathogenic rotavirus was detected by a p-type FET biosensor based on micropatterned RGO (MRGO-FET) [72]. Specific antibodies for rotavirus were covalently immobilized all over the RGO surface. As the virus concentration increased, the drain-source current proportionally decreased. The device was able to detect rotavirus in a concentration as low as $10^{2} \mathrm{PFU} \cdot \mathrm{mL}^{-1}$, which is lower than the concentrations detected by the conventional ELISA method.

The most toxic and carcinogenic food toxin, aflatoxin (AFB1), was sensitively detected by a graphene-based FET sensor developed by Basu et al. [90]. Electrophoretically deposited RGO films were integrated as active channel into the FET device. The high sensitivity of devices was possible because of enhanced biomolecule immobilization capability of RGO. AFB1 was detected in the sub-fM range, measured with a LOD of $0.1 \mathrm{fg} \cdot \mathrm{mL}^{-1}$.

Okamoto et al. reported a graphene-based FET sensor that allows the antigen-antibody reaction to occur within the electrical double layer in a buffer solution of high ionic strength [114]. Graphene was produced through the mechanical cleavage of graphite and the monolayer's surface was modified with antigen-binding fragments (Fab). Fab is the binding site component of conventional antibodies and presents a size of approximately $3 \mathrm{~nm}$. Thus, it is considered that the immunoreaction may occur inside the Debye length. Heat-shock proteins were used as target proteins to interact with Fab and were detected with high specificity and sensitivity by the immunoFET device. 


\subsection{Molybdenum Disulfide}

The 2D layered material molybdenum disulfide $\left(\mathrm{MoS}_{2}\right)$ belongs to the class of transition metal dichalcogenides and features unique optical and electronic properties that have triggered great interest in the application of FET-based sensors [115]. The layers are held together by weak van der Waals forces and a pristine $\mathrm{MoS}_{2}$ monolayer presents only $\sim 0.65 \mathrm{~nm}$ thick [116]. Unlike graphene, a gapless material, monolayer $\mathrm{MoS}_{2}$ exhibits a direct energy bandgap of $\sim 1.9 \mathrm{eV}$ which lowers leakage current and turns it an emerging material for designing highly sensitive FET biosensors $[51,108,117]$. Furthermore, the $2 \mathrm{D} \mathrm{MoS}{ }_{2}$ semiconductor offers high surface-to-volume ratio, facilitating surface functionalization and doping; high transparency, flexibility, and mechanical strength, making it an appealing material for flexible and transparent biodevices [116].

The first demonstration of the biofunctionalization of $\mathrm{MoS}_{2}$ nanosheets for designing a liquid-phase FET biosensor was reported by Wang et al. [51]. The authors fabricated a FET device for real-time detection of PSA cancer biomarker. Specific antibodies for PSA protein recognition were immobilized onto the $\mathrm{MoS}_{2}$ film surface. The n-type device conductance increased upon PSA binding to antibody receptors. The novel immunosensor showed LOD of $375 \mathrm{fM}$ as well as high selectivity, exhibiting no response towards non-target proteins.

The detection of the same cancer biomarker was also reported by Lee et al. [50]. The team presented a $\mathrm{MoS}_{2}$-FET biosensor that does not require a dielectric layer due to the hydrophobicity nature of $\mathrm{MoS}_{2}$, which allows the direct adsorption of antibodies and an improved sensitivity of the device. Figure 5 a displays the schematic representation of this FET immunosensor, showing antibodies immobilized on the $\mathrm{MoS}_{2}$ nanosheets sensing area and PSA antigen selectively bound to the antibodies. Figure $5 \mathrm{~b}$ exhibits the sensor response to various concentrations of PSA, which was detected with a LOD as low as $1 \mathrm{pg} \cdot \mathrm{mL}^{-1}$, a value much lower than the clinical cut-off.

(a)

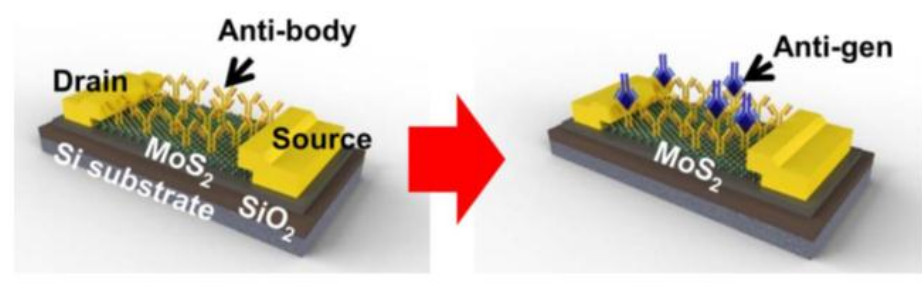

(b)

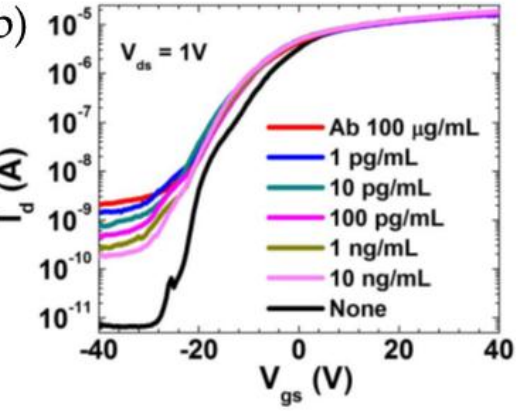

Figure 5. (a) Scheme showing the structure of the FET immunosensor based on $\mathrm{MoS}_{2}$ nanosheets as sensing channel. PSA antibodies are physiosorbed onto $\mathrm{MoS}_{2}$ and the antigen is selectively bound to the antibodies; (b) Transfer curves of the $\mathrm{MoS}_{2}$-FET immunosensor under different PSA concentrations. The analyte binding caused current increase. Lee et al. are fully acknowledged for the images [50].

\subsection{Titanium Dioxide}

The biocompatibility combined with the environmentally friendly character of nanostructured titanium dioxide $\left(\mathrm{TiO}_{2}\right)$ make this material an excellent perspective interface for the development of biosensing devices [118]. Moreover, $\mathrm{TiO}_{2}$ nanomaterial has a large specific surface area, shows a wide bandgap energy (between 1.8 and $4.1 \mathrm{eV}$ ), and possesses the ability of accepting electrons, thus the electrons resulting from the bioreceptor-analyte coupling can be gathered by $\mathrm{TiO}_{2}$ [119]. $\mathrm{Chu}$ et al. demonstrated a FET immunosensor based on $\mathrm{TiO}_{2}$ nanowires for the detection of rabbit immunoglobulin $\mathrm{G}(\mathrm{IgG})$ protein [120]. Specific antibodies for rabbit IgG were encapsulated on the 1D $\mathrm{TiO}_{2}$ surface by the electrochemical polymerization of polypyrrole propylic acid in order to immobilize antibodies on specific regions. Biomolecules needed to be encapsulated because the material surface 
stability hinders the directly immobilization of antibodies or antigens. The target protein was detected in the range from $119 \mathrm{pg} \cdot \mathrm{mL}^{-1}$ to $5.95 \mathrm{ng} \cdot \mathrm{mL}^{-1}$, with the application of a drain-source voltage of $5 \mathrm{~V}$.

\subsection{Zinc Oxide}

Nanostructured zinc oxide $(\mathrm{ZnO})$ is a semiconductor with a wide bandgap energy of $3.37 \mathrm{eV}$ [121]. $\mathrm{ZnO}$ is a suitable material for biosensing applications due to its biocompatibility with low toxicity to humans and a high isoelectric point. It has been explored in the detection of enzymes, antibodies, DNA, etc. [122,123]. Recently, a highly sensitive and selective FET immunosensor based on $\mathrm{ZnO}$ was reported [53]. A thin $\mathrm{ZnO}$ nanofilm (50 $\mathrm{nm}$ thick) was grown onto the gate region to act as an n-type channel and monoclonal antibodies were biofunctionalized on it. The drain current increased as a function of the antigen concentration increase and EGFR, a biomarker overexpressed by breast cancer tumors, was detected with a LOD as low as $10 \mathrm{fM}$.

\subsection{Hybrid Nanomaterials}

The performance of FET-based biosensors can be tuned by incorporating other nanomaterials (metal, oxides and semiconductor nanoparticles) on the nanostructured channel to obtain a hybrid structure. Nanoparticles-based hybrid nanomaterials have gaining significant attention because they offer the possibility to combine the individual properties in one material, resulting in a novel material that may exhibit synergistic properties, contributing to improve the selectivity and sensitivity of biosensors [24,31].

The presence of nanoparticles on the nanomaterial surface increases the specific surface area, providing an even larger surface for recognizing an analyte, thus resulting in amplified signal transduction response and higher conductivity. The improved sensitivity of these hybrid-based sensors is also associated with increased interfacial capacitance caused by the capacitive coupling between the nanoparticles and the nanomaterial platform [124]. For instance, Mao et al. demonstrated the electrical protein binding detection by an immunosensor based on MWCNT decorated with gold nanoparticles-antibody conjugates [125]. The gold nanoparticles labeled with anti-horseradish antibodies were attached onto MWCNT surface through non-covalent binding. Biological recognition events between antibodies and horseradish peroxidase antigens caused changes in the drain current and proteins were found to be accurately detected in the order of $1 \mathrm{fM}$.

In a further work, Mao and co-workers reported the first highly sensitive and selective FET-based biosensor using RGO decorated with gold nanoparticles-antibody conjugates for protein detection (Figure 6a). Gold nanoparticles of $20 \mathrm{~nm}$ average size conjugated with IgG antibodies were immobilized on a thermally obtained RGO surface. The binding event of recognizing IgG target induced significant changes in electrical measurements of the device, achieving a detection limit as low as $2 \mathrm{ng} \cdot \mathrm{mL}^{-1}$ [126]. In another effort to develop a new method to design a FET graphene-hybrid biosensor, the same research team switched the RGO sensing platform to vertically-oriented graphene sheets which were directly grown on the substrate (Figure 6b). Graphene was also functionalized with gold nanoparticles conjugated with antibodies and the devices were able to detect IgG protein again with high sensitivity (down to $2 \mathrm{ng} \cdot \mathrm{mL}^{-1}$ ) [127].

Hybrid sensors have a great potential to detect a wide variety of proteins for disease diagnosis. In this direction, Myung et al. demonstrated a novel FET immunosensor based on RGO encapsulated nanoparticle for detecting breast cancer biomarker [52]. Graphene oxide layers enwrapped silicon oxide nanoparticles functionalized with APTES by electrostatic interactions. Then, the hybrid graphene-nanoparticles were assembled at the gate region and specific monoclonal antibodies for human epidermal growth factor receptor 2 (HER2) and EGFR protein biomarkers were immobilized on its surface. The p-type device presented a decrease in conductance upon biomolecule target binding, with LOD of 1 pM for HER2 and 100 pM for EGFR. Kwon et al. fabricated a FET immunosensor for human immunodeficiency virus (HIV) detection using graphene-conducting polymer nanoparticle arrays nanohybrids [86]. The close-packed carboxylated polypyrrole nanoparticles (CPPyNP) of 
approximately $20 \mathrm{~nm}$ in size increased the surface area, resulting in a synergistic effect. The biomarker HIV-2 gp36 antigen (HIV-2 Ag) was covalently anchored to the nanoparticles surface and allowed HIV antibodies recognition in a concentration as low as $1 \mathrm{pM}$.

(a)

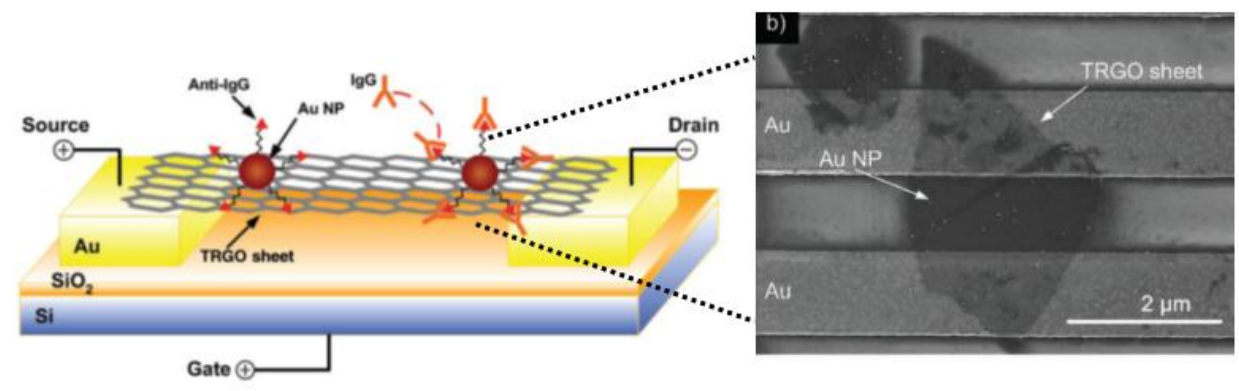

(b)

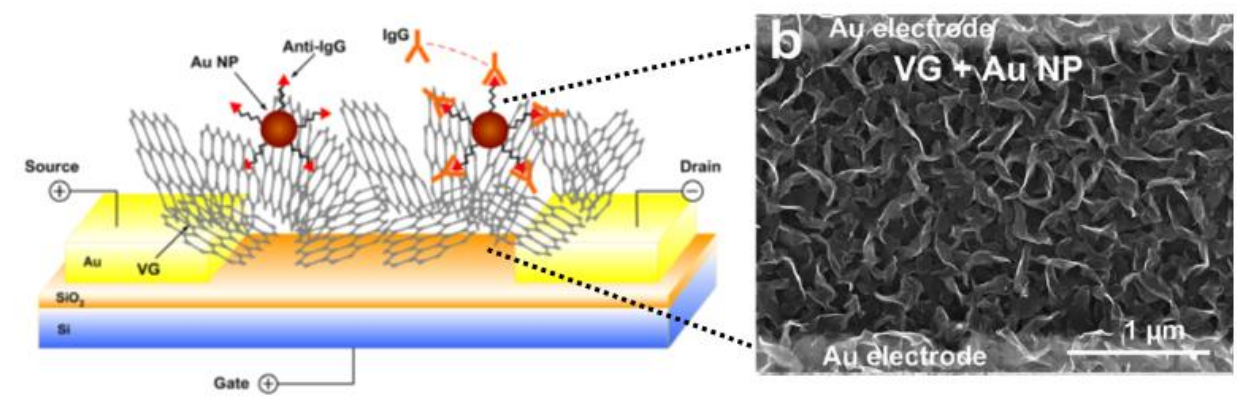

Figure 6. Representative schemes of FET immunosensors based on hybrid nanomaterials combined with corresponding SEM images of nanohybrids proposed by Mao and co-workers in different reports: (a) reduced graphene oxide decorated with gold nanoparticles-antibody conjugates [126]; and (b) vertically-oriented graphene sheets functionalized with gold nanoparticles conjugated with antibodies [127].

Zhang and co-workers developed a renewable FET immunosensor based on a graphene- $\mathrm{TiO}_{2}$ hybrid for detection of D-Dimer, a venous thromboembolism biomarker [62]. The FET device was fabricated by assembling a nanocomposite of $\mathrm{RGO}$ functionalized with $\mathrm{TiO}_{2}$ nanoparticles $\left(\mathrm{TiO}_{2} @ \mathrm{RGO}\right)$ onto a RGO surface in order to form a sandwich architecture on the sensing channel. The biodevice was capable of detecting the D-Dimer biomarker with excellent sensibility and specificity, achieving LOD of $10 \mathrm{pg} \cdot \mathrm{mL}^{-1}$ in PBS buffer and $100 \mathrm{pg} \cdot \mathrm{mL}^{-1}$ in serum, respectively. The reusability of the hybrid immunosensor was performed by irradiation of ultraviolet light to photocatalytically clean the organic molecules on the surface.

\subsection{Other Nanomaterials/Other Reports of Interest}

Starodub et al. fabricated a FET immunosensor based on $\mathrm{CeO}_{\mathrm{x}}$ as the gate surface to detect Salmonella typhimurium, a bacterium that causes food poisoning [67]. Thin $\mathrm{CeO}_{\mathrm{x}}$ layers were deposited on the gate region by electron beam evaporation. S. typhimurium was detected with sensitivity of 2-3 cells $\cdot \mathrm{mL}^{-1}$. The overall time of analysis was reduced from $30 \mathrm{~min}$ to $15-20 \mathrm{~min}$ by immobilizing specific antibodies labeled with horseradish peroxidase enzymes onto the gate surface, without altering the device sensitivity. Moreover, the devices were found to be reusable for up to five times without signal decrease by simply treating them with an acidic solution for the destruction of the antigen-antibody bindings.

Wu et al. proposed a FET sensor based on silicon nanobelt to detect prostate cancer biomarkers [88]. The n-type Si nanobelt immunoFET device was fabricated by functionalizing the nanobelt surface with APTES, glutaraldehyde, and antibodies specific for PSA recognition. The authors observed a decrease in drain current as a function of increasing PSA concentration, achieving a LOD of $5 \mathrm{pg} \cdot \mathrm{mL}^{-1}$. 
The sensitivity of the device was enhanced by introducing arginine molecules between APTES and glutaraldehyde, providing a more effective space region for antigen binding, and PSA was detected in concentration levels as low as $50 \mathrm{fg} \cdot \mathrm{mL}^{-1}$.

A FET immunosensor based on gold nanoparticles capped with self-assembled monolayers (SAM) of alkanethiol molecules deposited onto a gold surface was fabricated for detecting hemoglobin-A1c (HbA1c), an important index for diabetes [65]. HbA1c antibodies were stably immobilized on SAM by the end functional groups of thiols. Gold nanoparticles played an important role in the sensor's sensitivity because they possess high surface-to-volume ratio, thus offering more sites to immobilize biomolecules. The immuno device was capable of detecting the antigen in concentrations in the order of $\mathrm{ng} \cdot \mathrm{mL}^{-1}$.

Conventional FET sensors based on SiNW exhibit very low LOD, however they suffer from device instability, device-to-device variations, and discrete dopant fluctuations. An alternative to these drawbacks was demonstrated by using silicon nanogratings (SiNG) rather than SiNW [64]. The SiNG devices were fabricated using p-doped silicon-on-insulator substrates that were subjected to etching steps, thermal surface oxidation, and annealing. The biodevices presented higher electrical stability and reproducibility when exposed to buffer solution, being capable of detecting insulin, a diabetes-related hormone, with LOD down to $10 \mathrm{fM}$, both in buffer and diluted human serum.

C-reactive protein was ultrasensitively detected by a FET immunosensor based on an organic semiconductor surface composed of poly-3-hexyl thiophene (P3HT) [89]. Monoclonal anti-CRP antibodies were immobilized by physical adsorption onto the gate without any previous surface treatment. The transfer characteristics of the immunosensor showed a reduction in current with increasing concentrations of CRP and a LOD of $2 \mathrm{pM}$.

Multiplexed FET immunosensors are able to give insights on differential diagnosis. For instance, Cheng et al. reported a multianalyte immunoFET capable of detecting two lung cancer tumor markers [128]. Both cytokeratin 19 fragments (CYFRA21-1) and neuron-specific enolase (NSE) were quantitatively detected at the same time. The microdevice was fabricated through two FET integrated on the same chip and each transistor gate was biofunctionalized with different specific antibodies. CYFRA21-1 and NSE were detected with LOD of 1 and $100 \mathrm{ng} \cdot \mathrm{mL}^{-1}$, respectively. These results suggest a potential to easily identify different lung cancer types.

Label-free FET sensing also plays an important role on the early infection detection of agriculture plagues. Citrus tristeza virus and Xylella fastidiosa bacterium were detected by a FET biosensor using n-type indium phosphide (InP) as a biosensing platform [77]. InP substrate was aminated and PEGylated prior to the antibodies immobilization. The immunoFET detected phytopathogens with sensitivity of $2 \mathrm{nM}$, this value being comparable with highly sensitive biosensing electrochemical approaches.

\section{Aptamers Instead of Antibodies}

Aptamers consist of artificial oligonucleotide sequences (peptides or nucleic acids) which can recognize and bind to a wide range of targets including amino acids, proteins, enzymes, peptides, metal ions, small chemicals, viruses, and even cells with remarkable specificity and affinity [129]. Aptamers are produced through the in vitro selection and amplification of populations of random sequence oligonucleotide libraries, known as the SELEX process (selection evolution of ligands by exponential enrichment) [130].

This new class of synthetic molecules was first reported in 1990 [130,131]. Aptamers are known as antibody mimics and they have drawn much attention as promising alternatives to conventional antibodies in the design of novel FET-based immunosensors. Aptamers are capable of offering some advantages over antibodies: as they are synthetic molecules, they are chemically produced with high accuracy and reproducibility, without the use of animals or cell cultures; their production is less expensive and time-consuming than the whole process to generate specific monoclonal antibodies; and they exhibit high chemical stability in several buffer conditions, without losing bioactivity $[129,132,133]$. The greatest advantage of using aptamers instead of antibodies is their small size (approximately 
1-2 nm), a property that makes them shorter than the Debye length. Therefore, the biorecognition event between the target analyte and the aptamer may occur within the electrical double layer, even in physiological solutions of high ionic strength, resulting in improved sensitivity and a broader range of analytes [134].

Recently, various FET-based immunosensors using aptamers immobilized on nanomaterial sensing channels were reported [135-143]. For instance, So et al. firstly demonstrated a FET biosensor based on SWCNT using aptamers as bioreceptors. Thrombin aptamers were covalently immobilized onto the surface of SWCNT previously treated with carbodiimidazole-activated Tween 20 (CDI-Tween). The SWCNT-FET sensor presented a conductance decrease upon aptamer-target binding, being able to detect thrombin, a coagulation protein, with a LOD of $10 \mathrm{ng} \cdot \mathrm{mL}^{-1}$ [140]. Maehashi et al. fabricated a SWCNT-FET immunosensor for immunoglobulin E (IgE) detection [137]. IgE is a protein overexpressed by individuals with immune deficiency diseases. SWCNT channel was covalently modified with anti-IgE aptamers using PBASE as a linker molecule. The presence of IgE caused a sharp decrease in the drain-source current, indicating that the recognition event occurred inside the Debye layer. The dissociation constant for the reactions between aptamers and IgE was found to be $1.9 \times 10^{-9} \mathrm{M}$. Ohno et al. reported the detection of the same protein (IgE) by a graphene-FET immunosensor [138]. Anti-IgE aptamer DNA oligonucleotides of approximately $3 \mathrm{~nm}$ in size were covalently immobilized on the graphene channel surface through a linker molecule (PBASE). The drain current was found to be directly dependent on the $\mathrm{IgE}$ concentration and a dissociation constant of $47 \mathrm{nM}$ was estimated.

FET sensors using aptamers have been employed for the detection of disease biomarkers. For example, the detection of VEGF for cancer diagnosis was demonstrated by a SiNW-FET sensor modified with VEGF RNA aptamers [136]. Charged VEGF molecules on the surface of SiNW acted as electrically positive point-charges in both p-type and n-type SiNW-FET sensors. They were detected with LOD of $1.04 \mathrm{nM}$ and $104 \mathrm{pM}$ for n-type and p-type SiNW-FET, respectively. Interferon-gamma (IFN- $\gamma$ ) can be used as a biomarker to diagnose infectious diseases like tuberculosis [135]. This cytokine was sensitively detected through a graphene-FET immunosensor using IFN- $\gamma$ DNA aptamers immobilized on the graphene surface. The binding of IFN- $\gamma$ caused an increase in current across the graphene channel with increasing concentrations of IFN- $\gamma$, achieving LOD as low as $83 \mathrm{pM}$. Abnormal levels of CEA tumor marker were detected by a FET sensor fabricated using carboxylated polypyrrole multidimensional nanotubes (C-PPy MNTs) conjugated with CEA-binding aptamers [139]. The FET-aptasensor presented a p-type behavior since the drain-source current increased with the application of negative gate voltages. CEA was ultrasensitively detected, with a LOD of $1 \mathrm{fg} \cdot \mathrm{mL}^{-1}$, being a value $2-3$-fold lower than those previously reported.

Aptamer-based sensors are able to directly detect small molecules and weakly charged analytes. For example, Wang et al. reported a graphene-FET device to detect the small molecule steroid hormone dehydroepiandrosterone sulfate (DHEA-S) [141]. The sensing surface was prepared by anchoring a short DNA sequence complementary to the aptamer onto the graphene surface, thus forming an aptamer-DNA anchor hybrid layer. The analyte (DHEA-S)-aptamer binding changes the aptamer conformation, releasing the aptamer from the graphene surface, and consequently inducing changes in graphene conductance. DHEA-S biomarker was detected with high specificity, achieving a clinically relevant detection limit $(44.7 \mathrm{nM})$. Their findings demonstrate the potential of an aptamer-based FET sensor to detect other important low-charged small molecules in the biomedical field.

\section{Conclusions and Future Perspectives}

This review presents recent trends on FET-based immunosensors for the label-free detection of a broad range of analytes. The most recent reports have demonstrated a growing interest on the application of various nanomaterials such as silicon nanowires, carbon nanotubes, graphene, molybdenum disulfide, and others as sensing channels of FET-based devices. Nanostructured materials exhibit excellent physicochemical properties including high specific surface area and chemical stability, which make them attractive platforms for immobilizing specific antibodies to design novel 
FET immunosensors with improved specificity and sensitivity. These nanomaterials-based FET immunosensors have shown very low detection limits towards biomolecules such as protein disease biomarkers, pathogenic microorganisms like bacteria and viruses, and environmental pollutants like toxins, pesticides, and herbicides.

The detection of analytes in low ionic strength buffers and desalted serum by FET immunosensors has been described. However, the direct detection of antigen-antibody reactions in physiological solutions without sample pretreatment has proven to be a challenging undertaking. Therefore, the use of aptamers instead of antibodies has been reported as an alternative to bring the biorecognition event within the electrical double layer even under high ionic strength conditions.

In summary, research regarding FET-based immuno devices appreciably increased in the last years, demonstrating countless opportunities to explore these biosensors as promising alternatives to conventional immunoassays, especially for the early-stage detection of disease biomarkers. The use of nanomaterials as sensing channels enables the design of immunosensors with enhanced performance, opening new prospects in the development of highly sensitive, miniaturized, and unlabeled immuno devices for PoC applications and simultaneous multiplexed immunoassays.

Acknowledgments: The authors acknowledge the financial assistance provided by The São Paulo Research Foundation (FAPESP, project \#2013/22127-2 and grant \#2016/04739-9) and the National Council for Scientific and Technological Development (CNPq).

Conflicts of Interest: The authors declare no conflict of interest.

\section{Abbreviations}

The following abbreviations are used in this manuscript:

$\begin{array}{ll}\lambda_{D} & \text { Debye length } \\ \text { AFB1 } & \text { aflatoxin } \\ \text { AFP } & \text {-fetoprotein } \\ \text { APTES } & \text { 3-aminopropyltriethoxysilane } \\ \text { BSA } & \text { bovine serum albumin } \\ \text { CA 19-9 } & \text { carbohydrate antigen 19-9 } \\ \text { CDR } & \text { complementarity determining regions } \\ \text { CEA } & \text { carcinoembryonic antigen } \\ \text { CeO } & \text { cerium oxide } \\ \text { CPPyNP } & \text { carboxylated polypirrole nanoparticles } \\ \text { CRP } & \text { C-reactive protein } \\ \text { cTnI } & \text { cardiac troponin I } \\ \text { CVD } & \text { chemical vapor deposition } \\ \text { CYFRA21-1 } & \text { cytokeratin 19 fragments } \\ \text { DHEA-S } & \text { dehydroepiandrosterone sulfate } \\ \text { EDC } & \text { 1-ethyl-3-(3-dimethylaminopropyl) carbodiimide } \\ \text { EGFR } & \text { epidermal growth factor receptor } \\ \text { ELISA } & \text { enzyme-linked immunosorbent assay } \\ \text { Fab } & \text { antigen-binding fragments } \\ \text { FET } & \text { field-effect transistor } \\ \text { HER2 } & \text { human epidermal growth factor receptor 2 } \\ \text { HBsAg } & \text { hepatitis B marker } \\ \text { HIV } & \text { human immunodeficiency virus } \\ \text { InP } & \text { indium phosphide } \\ \text { IDS } & \text { drain-source current } \\ \text { IFN- } \gamma & \text { interferon-gamma } \\ \text { IgE } & \text { immunoglobulin E } \\ \text { IgG } & \text { immunoglobulin G } \\ \text { IL-6 } & \text { interleukin-6 } \\ \text { IL-8 } & \text { interleukin-8 } \\ \text { ISFET } & \text { ion-sensitive field effect transistor } \\ \text { LOD } & \text { limit of detection } \\ \text { MCRL } & \text { microcystin-LR } \\ & \end{array}$




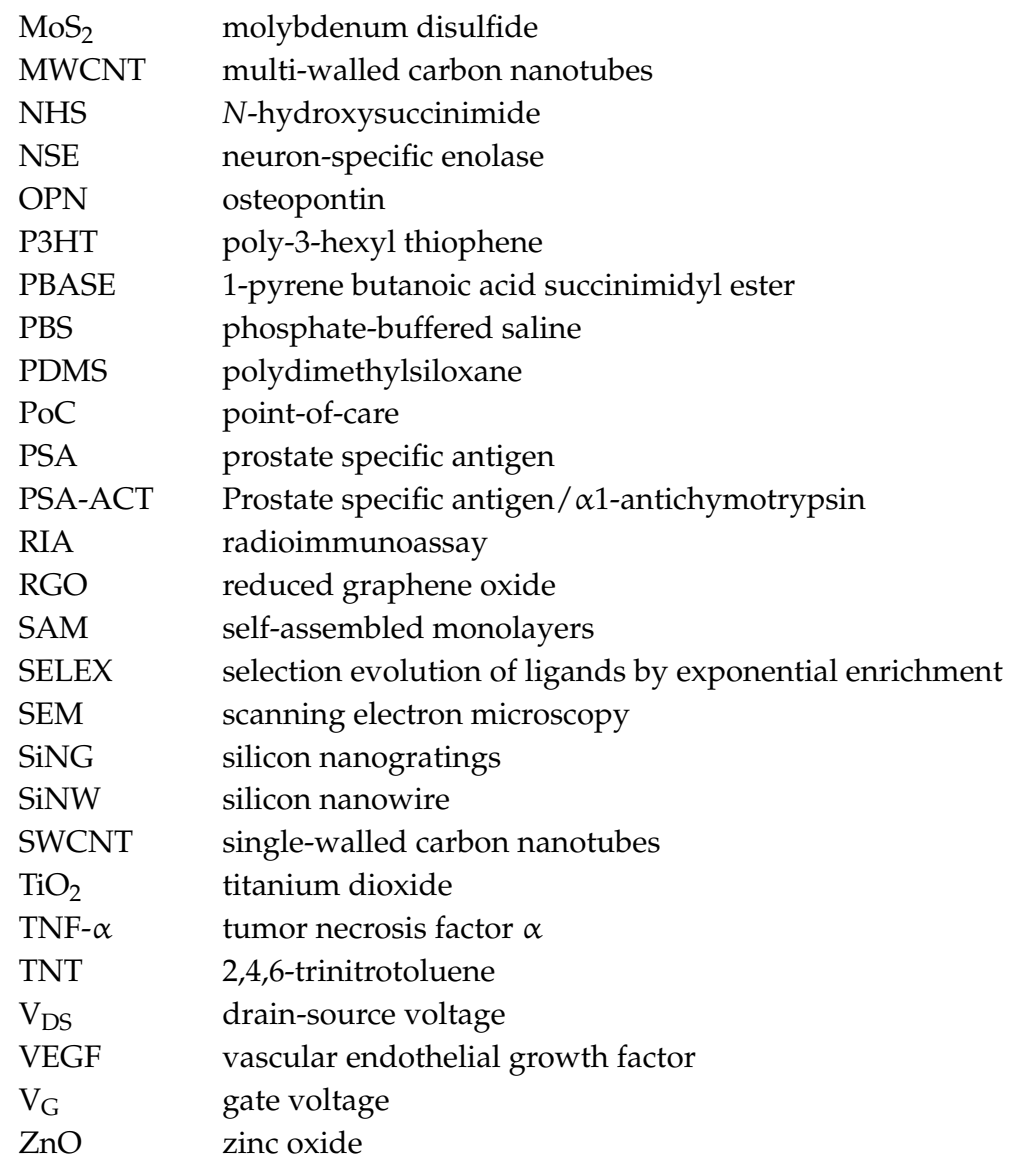

\section{References}

1. Freire, R.S.; Pessoa, C.A.; Mello, L.D.; Kubota, L.T. Direct electron transfer: An approach for electrochemical biosensors with higher selectivity and sensitivity. J. Braz. Chem. Soc. 2003, 14, 230-243. [CrossRef]

2. Thevenot, D.R.; Toth, K.; Durst, R.A.; Wilson, G.S. Electrochemical biosensors: Recommended definitions and classification. Biosens. Bioelectron. 2001, 16, 121-131. [CrossRef] [PubMed]

3. Luppa, P.B.; Sokoll, L.J.; Chan, D.W. Immunosensors-Principles and applications to clinical chemistry. Clin. Chim. Acta 2001, 314, 1-26. [CrossRef]

4. Conroy, P.J.; Hearty, S.; Leonard, P.; O'Kennedy, R.J. Antibody production, design and use for biosensor-based applications. Semin. Cell Dev. Biol. 2009, 20, 10-26. [CrossRef] [PubMed]

5. Viguier, C.; Lynam, C.; O'Kennedy, R. Trends and perspectives in immunosensors. In Antibodies Applications and New Developments; 2012; pp. 184-208. Available online: http://ebooks.benthamscience.com/book/ 9781608052646/ (accessed on 20 October 2016).

6. Hock, B. Antibodies for immunosensors-A review. Anal. Chim. Acta 1997, 347, 177-186. [CrossRef]

7. Wang, J. Electrochemical biosensors: Towards point-of-care cancer diagnostics. Biosens. Bioelectron. 2006, 21, 1887-1892. [CrossRef] [PubMed]

8. Song, Y.; Luo, Y.N.; Zhu, C.Z.; Li, H.; Du, D.; Lin, Y.H. Recent advances in electrochemical biosensors based on graphene two-dimensional nanomaterials. Biosens. Bioelectron. 2016, 76, 195-212. [CrossRef] [PubMed]

9. Luo, X.L.; Davis, J.J. Electrical biosensors and the label free detection of protein disease biomarkers. Chem. Soc. Rev. 2013, 42, 5944-5962. [CrossRef] [PubMed]

10. Porstmann, T.; Kiessig, S.T. Enzyme-immunoassay techniques-An overview. J. Immunol. Methods 1992, 150, 5-21. [CrossRef]

11. Lee, T.M.H. Over-the-counter biosensors: Past, present, and future. Sensors 2008, 8, 5535-5559. [CrossRef]

12. Ivnitski, D.; Abdel-Hamid, I.; Atanasov, P.; Wilkins, E. Biosensors for detection of pathogenic bacteria. Biosens. Bioelectron. 1999, 14, 599-624. [CrossRef] 
13. Yalow, R.S.; Berson, S.A. Immunoassay of endogenous plasma insulin in man. J. Clin. Investig. 1960, 39, 1157-1175. [CrossRef] [PubMed]

14. Holford, T.R.J.; Davis, F.; Higson, S.P.J. Recent trends in antibody based sensors. Biosens. Bioelectron. 2012, 34, 12-24. [CrossRef] [PubMed]

15. Centi, S.; Laschi, S.; Mascini, M. Strategies for electrochemical detection in immunochemistry. Bioanalysis 2009, 1, 1271-1291. [CrossRef] [PubMed]

16. Marco, M.P.; Gee, S.; Hammock, B.D. Immunochemical techniques for environmental-analysis. 1. Immunosensors. Trends Anal. Chem. 1995, 14, 341-350. [CrossRef]

17. Zachariah, E.S.; Gopalakrishnakone, P.; Neuzil, P. Immunologically sensitive field-effect transistors. In Encyclopedia of Medical Devices and Instrumentation; John Wiley \& Sons: New York, NY, USA, 2006.

18. Poghossian, A.; Schoning, M.J. Label-free sensing of biomolecules with field-effect devices for clinical applications. Electroanal 2014, 26, 1197-1213. [CrossRef]

19. Schoning, M.J.; Poghossian, A. Bio feds (field-effect devices): State-of-the-art and new directions. Electroanal 2006, 18, 1893-1900. [CrossRef]

20. Bergveld, P. Development, operation, and application of ion-sensitive field-effect transistor as a tool for electrophysiology. IEEE Trans. Biomed. Eng. 1972, 19, 342-351. [CrossRef] [PubMed]

21. Bergveld, P. A critical-evaluation of direct electrical protein-detection methods. Biosens. Bioelectron. 1991, 6, 55-72. [CrossRef]

22. Bergveld, P. The future of biosensors. Sens. Actuat. A Phys. 1996, 56, 65-73. [CrossRef]

23. Schasfoort, R.B.M.; Bergveld, P.; Kooyman, R.P.H.; Greve, J. Possibilities and limitations of direct detection of protein charges by means of an immunological field-effect transistor. Anal. Chim. Acta 1990, 238, 323-329. [CrossRef]

24. Yin, P.T.; Shah, S.; Chhowalla, M.; Lee, K.B. Design, synthesis, and characterization of graphene-nanoparticle hybrid materials for bioapplications. Chem. Rev. 2015, 115, 2483-2531. [CrossRef] [PubMed]

25. Ohno, Y.; Maehashi, K.; Yamashiro, Y.; Matsumoto, K. Electrolyte-gated graphene field-effect transistors for detecting ph protein adsorption. Nano Lett. 2009, 9, 3318-3322. [CrossRef] [PubMed]

26. Ang, P.K.; Chen, W.; Wee, A.T.S.; Loh, K.P. Solution-gated epitaxial graphene as ph sensor. J. Am. Chem. Soc. 2008, 130, 14392-14393. [CrossRef] [PubMed]

27. Di Bartolomeo, A.; Rinzan, M.; Boyd, A.K.; Yang, Y.; Guadagno, L.; Giubileo, F.; Barbara, P. Electrical properties and memory effects of field-effect transistors from networks of single-and double-walled carbon nanotubes. Nanotechnology 2010, 21, 115204. [CrossRef] [PubMed]

28. Cramer, T.; Campana, A.; Leonardi, F.; Casalini, S.; Kyndiah, A.; Murgia, M.; Biscarini, F. Water-gated organic field effect transistors-opportunities for biochemical sensing and extracellular signal transduction. J. Mater. Chem. B 2013, 1, 3728-3741. [CrossRef]

29. Patolsky, F.; Zheng, G.F.; Lieber, C.M. Nanowire-based biosensors. Anal. Chem. 2006, 78, 4260-4269. [CrossRef] [PubMed]

30. Schenk, J.F. Theory, Design, and Biomedical Applications of Solid State Chemical Sensors; Cheung, P.W., Ed.; CRC Press: West Palm Beach, FL, USA, 1978; p. 296.

31. Yin, P.T.; Kim, T.H.; Choi, J.W.; Lee, K.B. Prospects for graphene-nanoparticle-based hybrid sensors. Phys. Chem. Chem. Phys. 2013, 15, 12785-12799. [CrossRef] [PubMed]

32. Pumera, M. Graphene in biosensing. Mater. Today 2011, 14, 308-315. [CrossRef]

33. Ramnani, P.; Saucedo, N.M.; Mulchandani, A. Carbon nanomaterial-based electrochemical biosensors for label-free sensing of environmental pollutants. Chemosphere 2016, 143, 85-98. [CrossRef] [PubMed]

34. Nehra, A.; Singh, K.P. Current trends in nanomaterial embedded field effect transistor-based biosensor. Biosens. Bioelectron. 2015, 74, 731-743. [CrossRef] [PubMed]

35. Lin, P.; Yan, F. Organic thin-film transistors for chemical and biological sensing. Adv. Mater. 2012, $24,34-51$. [CrossRef] [PubMed]

36. He, R.X.; Lin, P.; Liu, Z.K.; Zhu, H.W.; Zhao, X.Z.; Chan, H.L.W.; Yan, F. Solution-gated graphene field effect transistors integrated in microfluidic systems and used for flow velocity detection. Nano Lett. 2012, 12, 1404-1409. [CrossRef] [PubMed]

37. Mu, L.; Chang, Y.; Sawtelle, S.D.; Wipf, M.; Duan, X.X.; Reed, M.A. Silicon nanowire field-effect transistors-a versatile class of potentiometric nanobiosensors. IEEE Access 2015, 3, 287-302. [CrossRef]

38. Debye, P. Reaction rates in ionic solutions. J. Electrochem. Soc. 1942, 82, 265-272. [CrossRef] 
39. Russel, W.B.; Saville, D.A.; Schowalter, W.R. Colloidal Dispersions; Cambridge University Press: Cambridge, UK, 1989.

40. Elnathan, R.; Kwiat, M.; Pevzner, A.; Engel, Y.; Burstein, L.; Khatchtourints, A.; Lichtenstein, A.; Kantaev, R.; Patolsky, F. Biorecognition layer engineering: Overcoming screening limitations of nanowire-based fet devices. Nano Lett. 2012, 12, 5245-5254. [CrossRef] [PubMed]

41. Stern, E.; Wagner, R.; Sigworth, F.J.; Breaker, R.; Fahmy, T.M.; Reed, M.A. Importance of the debye screening length on nanowire field effect transistor sensors. Nano Lett. 2007, 7, 3405-3409. [CrossRef] [PubMed]

42. Casal, P.; Wen, X.J.; Gupta, S.; Nicholson, T.; Wang, Y.J.; Theiss, A.; Bhushan, B.; Brillson, L.; Lu, W.; Lee, S.C. Immunofet feasibility in physiological salt environments. Philos. Trans. R. Soc. A 2012, 370, 2474-2488. [CrossRef] [PubMed]

43. Schoning, M.J.; Poghossian, A. Recent advances in biologically sensitive field-effect transistors (biofets). Analyst 2002, 127, 1137-1151. [CrossRef] [PubMed]

44. Ansari, A.A.; Alhoshan, M.; Alsalhi, M.S.; Aldwayyan, A.S. Prospects of nanotechnology in clinical immunodiagnostics. Sensors 2010, 10, 6535-6581. [CrossRef] [PubMed]

45. Zhu, C.Z.; Yang, G.H.; Li, H.; Du, D.; Lin, Y.H. Electrochemical sensors and biosensors based on nanomaterials and nanostructures. Anal. Chem. 2015, 87, 230-249. [CrossRef] [PubMed]

46. Hu, W.H.; Li, C.M. Nanomaterial-based advanced immunoassays. Wires Nanomed. Nanobiotechnol. 2011, 3, 119-133. [CrossRef] [PubMed]

47. Lu, N.; Gao, A.R.; Dai, P.F.; Mao, H.J.; Zuo, X.L.; Fan, C.H.; Wang, Y.L.; Li, T. Ultrasensitive detection of dual cancer biomarkers with integrated cmos-compatible nanowire arrays. Anal. Chem. 2015, 87, 11203-11208. [CrossRef] [PubMed]

48. Huang, Y.W.; Wu, C.S.; Chuang, C.K.; Pang, S.T.; Pan, T.M.; Yang, Y.S.; Ko, F.H. Real-time and label-free detection of the prostate-specific antigen in human serum by a polycrystalline silicon nanowire field-effect transistor biosensor. Anal. Chem. 2013, 85, 7912-7918. [CrossRef] [PubMed]

49. Kim, D.J.; Sohn, I.Y.; Jung, J.H.; Yoon, O.J.; Lee, N.E.; Park, J.S. Reduced graphene oxide field-effect transistor for label-free femtomolar protein detection. Biosens. Bioelectron. 2013, 41, 621-626. [CrossRef] [PubMed]

50. Lee, J.; Dak, P.; Lee, Y.; Park, H.; Choi, W.; Alam, M.A.; Kim, S. Two-dimensional layered mos2 biosensors enable highly sensitive detection of biomolecules. Sci. Rep. 2014, 4, 7352. [CrossRef] [PubMed]

51. Wang, L.; Wang, Y.; Wong, J.I.; Palacios, T.; Kong, J.; Yang, H.Y. Functionalized mos2 nanosheet-based field-effect biosensor for label-free sensitive detection of cancer marker proteins in solution. Small 2014, 10, 1101-1105. [CrossRef] [PubMed]

52. Myung, S.; Solanki, A.; Kim, C.; Park, J.; Kim, K.S.; Lee, K.B. Graphene-encapsulated nanoparticle-based biosensor for the selective detection of cancer biomarkers. Adv. Mater. 2011, 23, 2221-2225. [CrossRef] [PubMed]

53. Reyes, P.I.; Ku, C.J.; Duan, Z.Q.; Lu, Y.C.; Solanki, A.; Lee, K.B. Zno thin film transistor immunosensor with high sensitivity and selectivity. Appl. Phys. Lett. 2011, 98, 173702. [CrossRef]

54. Zhu, K.Y.; Zhang, Y.; Li, Z.Y.; Zhou, F.; Feng, K.; Dou, H.Q.; Wang, T. Simultaneous detection of alpha-fetoprotein and carcinoembryonic antigen based on si nanowire field-effect transistors. Sensors 2015, 15, 19225-19236. [CrossRef] [PubMed]

55. Zhang, Y.L.; Chen, R.M.; Xu, L.; Ning, Y.; Xie, S.G.; Zhang, G.J. Silicon nanowire biosensor for highly sensitive and multiplexed detection of oral squamous cell carcinoma biomarkers in saliva. Anal. Sci. 2015, 31, 73-78. [CrossRef] [PubMed]

56. Jung, J.H.; Sohn, I.Y.; Kim, D.J.; Kim, B.Y.; Fang, M.; Lee, N.E. Enhancement of protein detection performance in field-effect transistors with polymer residue-free graphene channel. Carbon 2013, 62, 312-321. [CrossRef]

57. Chen, H.C.; Chen, Y.T.; Tsai, R.Y.; Chen, M.C.; Chen, S.L.; Xiao, M.C.; Chen, C.L.; Hua, M.Y. A sensitive and selective magnetic graphene composite-modified polycrystalline-silicon nanowire field-effect transistor for bladder cancer diagnosis. Biosens. Bioelectron. 2015, 66, 198-207. [CrossRef] [PubMed]

58. Justino, C.I.L.; Freitas, A.C.; Amaral, J.P.; Rocha-Santos, T.A.P.; CardosoC, S.; Duarte, A.C. Disposable immunosensors for c-reactive protein based on carbon nanotubes field effect transistors. Talanta 2013, 108, 165-170. [CrossRef] [PubMed]

59. Kim, K.; Park, C.; Kwon, D.; Kim, D.; Meyyappan, M.; Jeon, S.; Lee, J.S. Silicon nanowire biosensors for detection of cardiac troponin i (ctni) with high sensitivity. Biosens. Bioelectron. 2016, 77, 695-701. [CrossRef] [PubMed] 
60. Kong, T.; Su, R.G.; Zhang, B.B.; Zhang, Q.; Cheng, G.S. Cmos-compatible, label-free silicon-nanowire biosensors to detect cardiac troponin i for acute myocardial infarction diagnosis. Biosens. Bioelectron. 2012, 34, 267-272. [CrossRef] [PubMed]

61. Lu, N.; Dai, P.F.; Gao, A.R.; Valiaho, J.; Kallio, P.; Wang, Y.L.; Li, T. Label-free and rapid electrical detection of htsh with cmos-compatible silicon nanowire transistor arrays. ACS Appl. Mater. Interfaces 2014, 6, 20378-20384. [CrossRef] [PubMed]

62. Zhang, C.; Xu, J.-Q.; Li, T.; Huang, L.; Pang, D.-W.; Ning, Y.; Huang, W.-H.; Zhang, Z.; Zhang, G.-J. Photocatalysis-induced renewable field-effect transistor for protein detection. Anal. Chem. 2016, 88, 4048-4054. [CrossRef] [PubMed]

63. Oh, J.; Yoo, G.; Chang, Y.W.; Kim, H.J.; Jose, J.; Kim, E.; Pyun, J.C.; Yoo, K.H. A carbon nanotube metal semiconductor field effect transistor-based biosensor for detection of amyloid-beta in human serum. Biosens. Bioelectron. 2013, 50, 345-350. [CrossRef] [PubMed]

64. Regonda, S.; Tian, R.H.; Gao, J.M.; Greene, S.; Ding, J.H.; Hu, W. Silicon multi-nanochannel fets to improve device uniformity/stability and femtomolar detection of insulin in serum. Biosens. Bioelectron. 2013, 45, 245-251. [CrossRef] [PubMed]

65. Xue, Q.N.; Bian, C.; Tong, J.H.; Sun, J.Z.; Zhang, H.; Xia, S.H. Fet immunosensor for hemoglobin a1c using a gold nanofilm grown by a seed-mediated technique and covered with mixed self-assembled monolayers. Microchim. Acta 2012, 176, 65-72. [CrossRef]

66. Lerner, M.B.; Goldsmith, B.R.; McMillon, R.; Dailey, J.; Pillai, S.; Singh, S.R.; Johnson, A.T.C. A carbon nanotube immunosensor for salmonella. Aip Adv. 2011, 1. [CrossRef]

67. Starodub, N.F.; Ogorodnijchuk, J.O. Immune biosensor based on the isfets for express determination of Salmonella typhimurium. Electroanal 2012, 24, 600-606. [CrossRef]

68. Chang, J.B.; Mao, S.; Zhang, Y.; Cui, S.M.; Zhou, G.H.; Wu, X.G.; Yang, C.H.; Chen, J.H. Ultrasonic-assisted self-assembly of monolayer graphene oxide for rapid detection of Escherichia coli bacteria. Nanoscale 2013, 5, 3620-3626. [CrossRef] [PubMed]

69. Garcia-Aljaro, C.; Cella, L.N.; Shirale, D.J.; Park, M.; Munoz, F.J.; Yates, M.V.; Mulchandani, A. Carbon nanotubes-based chemiresistive biosensors for detection of microorganisms. Biosens. Bioelectron. 2010, 26, 1437-1441. [CrossRef] [PubMed]

70. Huang, Y.X.; Dong, X.C.; Liu, Y.X.; Li, L.J.; Chen, P. Graphene-based biosensors for detection of bacteria and their metabolic activities. J. Mater. Chem. 2011, 21, 12358-12362. [CrossRef]

71. Yamada, K.; Kim, C.T.; Kim, J.H.; Chung, J.H.; Lee, H.G.; Jun, S. Single walled carbon nanotube-based junction biosensor for detection of Escherichia coli. PLoS ONE 2014, 9. [CrossRef] [PubMed]

72. Liu, F.; Kim, Y.H.; Cheon, D.S.; Seo, T.S. Micropatterned reduced graphene oxide based field-effect transistor for real-time virus detection. Sens. Actuat. B Chem. 2013, 186, 252-257. [CrossRef]

73. Wong, J.I.; Wang, L.; Shi, Y.M.; Palacios, T.; Kong, J.; Dong, X.C.; Yang, H.Y. Real-time, sensitive electrical detection of cryptosporidium parvum oocysts based on chemical vapor deposition-grown graphene. Appl. Phys. Lett. 2014, 104, 063705. [CrossRef]

74. Belkhamssa, N.; Justino, C.I.L.; Santos, P.S.M.; Cardoso, S.; Lopes, I.; Duarte, A.C.; Rocha-Santos, T.; Ksibi, M. Label-free disposable immunosensor for detection of atrazine. Talanta 2016, 146, 430-434. [CrossRef] [PubMed]

75. Wijaya, I.P.M.; Nie, T.J.; Gandhi, S.; Boro, R.; Palaniappan, A.; Hau, G.W.; Rodriguez, I.; Suri, C.R.; Mhaisalkar, S.G. Femtomolar detection of 2,4-dichlorophenoxyacetic acid herbicides via competitive immunoassays using microfluidic based carbon nanotube liquid gated transistor. Lab Chip 2010, 10, 634-638. [CrossRef] [PubMed]

76. Park, M.; Cella, L.N.; Chen, W.F.; Myung, N.V.; Mulchandani, A. Carbon nanotubes-based chemiresistive immunosensor for small molecules: Detection of nitroaromatic explosives. Biosens. Bioelectron. 2010, 26, 1297-1301. [CrossRef] [PubMed]

77. Moreau, A.L.D.; Janissen, R.; Santos, C.A.; Peroni, L.A.; Stach-Machado, D.R.; de Souza, A.A.; de Souza, A.P.; Cotta, M.A. Highly-sensitive and label-free indium phosphide biosensor for early phytopathogen diagnosis. Biosens. Bioelectron. 2012, 36, 62-68. [CrossRef] [PubMed]

78. Chiang, P.L.; Chou, T.C.; Wu, T.H.; Li, C.C.; Liao, C.D.; Lin, J.Y.; Tsai, M.H.; Tsai, C.C.; Sun, C.J.; Wang, C.H.; et al. Nanowire transistor-based ultrasensitive virus detection with reversible surface functionalization. Chem. Asian J. 2012, 7, 2073-2079. [CrossRef] [PubMed] 
79. Ivanov, Y.D.; Pleshakova, T.O.; Kozlov, A.F.; Malsagova, K.A.; Krohin, N.V.; Shumyantseva, V.V.; Shumov, I.D.; Popov, V.P.; Naumova, O.V.; Fomin, B.I.; et al. Soi nanowire for the high-sensitive detection of hbsag and alpha-fetoprotein. Lab Chip 2012, 12, 5104-5111. [CrossRef] [PubMed]

80. Sharma, A.; Hong, S.; Singh, R.; Jang, J. Single-walled carbon nanotube based transparent immunosensor for detection of a prostate cancer biomarker osteopontin. Anal. Chim. Acta 2015, 869, 68-73. [CrossRef] [PubMed]

81. Chen, H.; Choo, T.K.; Huang, J.F.; Wang, Y.; Liu, Y.J.; Platt, M.; Palaniappan, A.; Liedberg, B.; Tok, A.I.Y. Label-free electronic detection of interleukin-6 using horizontally aligned carbon nanotubes. Mater. Des. 2016, 90, 852-857. [CrossRef]

82. Tlili, C.; Myung, N.V.; Shetty, V.; Mulchandani, A. Label-free, chemiresistor immunosensor for stress biomarker cortisol in saliva. Biosens. Bioelectron. 2011, 26, 4382-4386. [CrossRef] [PubMed]

83. Lerner, M.B.; Dailey, J.; Goldsmith, B.R.; Brisson, D.; Johnson, A.T.C. Detecting lyme disease using antibody-functionalized single-walled carbon nanotube transistors. Biosens. Bioelectron. 2013, 45, 163-167. [CrossRef] [PubMed]

84. Lerner, M.B.; D'Souza, J.; Pazina, T.; Dailey, J.; Goldsmith, B.R.; Robinson, M.K.; Johnson, A.T.C. Hybrids of a genetically engineered antibody and a carbon nanotube transistor for detection of prostate cancer biomarkers. ACS Nano 2012, 6, 5143-5149. [CrossRef] [PubMed]

85. Yeh, C.H.; Kumar, V.; Moyano, D.R.; Wen, S.H.; Parashar, V.; Hsiao, S.H.; Srivastava, A.; Saxena, P.S.; Huang, K.P.; Chang, C.C.; et al. High-performance and high-sensitivity applications of graphene transistors with self-assembled monolayers. Biosens. Bioelectron. 2016, 77, 1008-1015. [CrossRef] [PubMed]

86. Kwon, O.S.; Lee, S.H.; Park, S.J.; An, J.H.; Song, H.S.; Kim, T.; Oh, J.H.; Bae, J.; Yoon, H.; Park, T.H.; et al. Large-scale graphene micropattern nano-biohybrids: High-performance transducers for fet-type flexible fluidic HIV immunoassays. Adv. Mater. 2013, 25, 4177-4185. [CrossRef] [PubMed]

87. Kim, B.Y.; Sohn, I.Y.; Lee, D.; Han, G.S.; Lee, W.I.; Jung, H.S.; Lee, N.E. Ultrarapid and ultrasensitive electrical detection of proteins in a three-dimensional biosensor with high capture efficiency. Nanoscale 2015, 7, 9844-9851. [CrossRef] [PubMed]

88. Wu, C.C.; Pan, T.M.; Wu, C.S.; Yen, L.C.; Chuang, C.K.; Pang, S.T.; Yang, Y.S.; Ko, F.H. Label-free detection of prostate specific antigen using a silicon nanobelt field-effect transistor. Int. J. Electrochem. Sci. 2012, 7, 4432-4442.

89. Magliulo, M.; De Tullio, D.; Vikholm-Lundin, I.; Albers, W.; Munter, T.; Manoli, K.; Palazzo, G.; Torsi, L. Label-free c-reactive protein electronic detection with an electrolyte-gated organic field-effect transistor-based immunosensor. Anal. Bioanal. Chem. 2016, 408, 3943-3952. [CrossRef] [PubMed]

90. Basu, J.; Datta, S.; RoyChaudhuri, C. A graphene field effect capacitive immunosensor for sub-femtomolar food toxin detection. Biosens. Bioelectron. 2015, 68, 544-549. [CrossRef] [PubMed]

91. Tan, F.; Saucedo, N.M.; Ramnani, P.; Mulchandani, A. Label-free electrical immunosensor for highly sensitive and specific detection of microcystin-lr in water samples. Environ. Sci. Technol. 2015, 49, 9256-9263. [CrossRef] [PubMed]

92. Hu, J.T.; Odom, T.W.; Lieber, C.M. Chemistry and physics in one dimension: Synthesis and properties of nanowires and nanotubes. Acc. Chem. Res. 1999, 32, 435-445. [CrossRef]

93. Cui, Y.; Duan, X.F.; Hu, J.T.; Lieber, C.M. Doping and electrical transport in silicon nanowires. J. Phys. Chem. B 2000, 104, 5213-5216. [CrossRef]

94. Hasan, M.; Huq, M.F.; Mahmood, Z.H. A review on electronic and optical properties of silicon nanowire and its different growth techniques. Springerplus 2013, 2, 151. [CrossRef] [PubMed]

95. Chen, K.I.; Li, B.R.; Chen, Y.T. Silicon nanowire field-effect transistor-based biosensors for biomedical diagnosis and cellular recording investigation. Nano Today 2011, 6, 131-154. [CrossRef]

96. Noor, M.O.; Krull, U.J. Silicon nanowires as field-effect transducers for biosensor development: A review. Anal. Chim. Acta 2014, 825, 1-25. [CrossRef] [PubMed]

97. Cui, Y.; Wei, Q.Q.; Park, H.K.; Lieber, C.M. Nanowire nanosensors for highly sensitive and selective detection of biological and chemical species. Science 2001, 293, 1289-1292. [CrossRef] [PubMed]

98. Puppo, F.; Doucey, M.-A.; Moh, T.S.Y.; Pandraud, G.; Sarro, P.M.; De Micheli, G.; Carrara, S. Femto-molar sensitive field effect transistor biosensors based on silicon nanowires and antibodies. In Proceedings of the 2013 IEEE Sensors Proceedings, Baltimore, MD, USA, 4-6 November 2013.

99. Popov, V.N. Carbon nanotubes: Properties and application. Mater. Sci. Eng. R 2004, 43, 61-102. [CrossRef] 
100. Iijima, S. Helical microtubules of graphitic carbon. Nature 1991, 354, 56-58. [CrossRef]

101. Iijima, S.; Ichihashi, T. Single-shell carbon nanotubes of 1-nm diameter. Nature 1993, 363, 603-605. [CrossRef]

102. Bethune, D.S.; Kiang, C.H.; Devries, M.S.; Gorman, G.; Savoy, R.; Vazquez, J.; Beyers, R. Cobalt-catalyzed growth of carbon nanotubes with single-atomic-layerwalls. Nature 1993, 363, 605-607. [CrossRef]

103. Sarkar, T.; Gao, Y.N.; Mulchandani, A. Carbon nanotubes-based label-free affinity sensors for environmental monitoring. Appl. Biochem. Biotechnol. 2013, 170, 1011-1025. [CrossRef] [PubMed]

104. Geim, A.K.; Novoselov, K.S. The rise of graphene. Nat. Mater. 2007, 6, 183-191. [CrossRef] [PubMed]

105. Novoselov, K.S.; Geim, A.K.; Morozov, S.V.; Jiang, D.; Zhang, Y.; Dubonos, S.V.; Grigorieva, I.V.; Firsov, A.A. Electric field effect in atomically thin carbon films. Science 2004, 306, 666-669. [CrossRef] [PubMed]

106. Park, S.; Ruoff, R.S. Chemical methods for the production of graphenes. Nat. Nanotechnol. 2009, 4, $217-224$. [CrossRef] [PubMed]

107. Guo, S.J.; Dong, S.J. Graphene nanosheet: Synthesis, molecular engineering, thin film, hybrids, and energy and analytical applications. Chem. Soc. Rev. 2011, 40, 2644-2672. [CrossRef] [PubMed]

108. Di Bartolomeo, A. Graphene schottky diodes: An experimental review of the rectifying graphene/ semiconductor heterojunction. Phys. Rep. 2016, 606, 1-58. [CrossRef]

109. Mas-Balleste, R.; Gomez-Navarro, C.; Gomez-Herrero, J.; Zamora, F. 2D materials: To graphene and beyond. Nanoscale 2011, 3, 20-30. [CrossRef] [PubMed]

110. Partoens, B.; Peeters, F.M. From graphene to graphite: Electronic structure around the k point. Phys. Rev. B 2006, 74, 075404. [CrossRef]

111. Schwierz, F. Graphene transistors. Nat. Nanotechnol. 2010, 5, 487-496. [CrossRef] [PubMed]

112. Di Bartolomeo, A.; Giubileo, F.; Santandrea, S.; Romeo, F.; Citro, R.; Schroeder, T.; Lupina, G. Charge transfer and partial pinning at the contacts as the origin of a double dip in the transfer characteristics of graphene-based field-effect transistors. Nanotechnology 2011, 22, 275702. [CrossRef] [PubMed]

113. Liu, Y.X.; Dong, X.C.; Chen, P. Biological and chemical sensors based on graphene materials. Chem. Soc. Rev. 2012, 41, 2283-2307. [CrossRef] [PubMed]

114. Okamoto, S.; Ohno, Y.; Maehashi, K.; Inoue, K.; Matsumoto, K. Immunosensors based on graphene field-effect transistors fabricated using antigen-binding fragment. Jpn. J. Appl. Phys. 2012, 51, 06FD08. [CrossRef]

115. Tong, X.; Ashalley, E.; Lin, F.; Li, H.D.; Wang, Z.M.M. Advances in mos2-based field effect transistors (fets). Nano-Micro Lett. 2015, 7, 203-218. [CrossRef]

116. Sarkar, D.; Liu, W.; Xie, X.J.; Anselmo, A.C.; Mitragotri, S.; Banerjee, K. Mos2 field-effect transistor for next-generation label-free biosensors. ACS Nano 2014, 8, 3992-4003. [CrossRef] [PubMed]

117. Sarkar, D.; Xie, X.J.; Kang, J.H.; Zhang, H.J.; Liu, W.; Navarrete, J.; Moskovits, M.; Banerjee, K. Functionalization of transition metal dichalcogenides with metallic nanoparticles: Implications for doping and gas-sensing. Nano Lett. 2015, 15, 2852-2862. [CrossRef] [PubMed]

118. Bai, J.; Zhou, B.X. Titanium dioxide nanomaterials for sensor applications. Chem. Rev. 2014, 114, 10131-10176. [CrossRef] [PubMed]

119. Wang, R.H.; Ruan, C.M.; Kanayeva, D.; Lassiter, K.; Li, Y.B. Tio2 nanowire bundle microelectrode based impedance immunosensor for rapid and sensitive detection of listeria monocytogenes. Nano Lett. 2008, 8, 2625-2631. [CrossRef] [PubMed]

120. Chu, Y.M.; Lin, C.C.; Chang, H.C.; Li, C.M.; Guo, C.X. Tio(2) nanowire fet device: Encapsulation of biomolecules by electro polymerized pyrrole propylic acid. Biosens. Bioelectron. 2011, 26, 2334-2340. [CrossRef] [PubMed]

121. Arya, S.K.; Saha, S.; Ramirez-Vick, J.E.; Gupta, V.; Bhansali, S.; Singh, S.P. Recent advances in zno nanostructures and thin films for biosensor applications: Review. Anal. Chim. Acta 2012, 737, 1-21. [CrossRef] [PubMed]

122. Yano, M.; Koike, K.; Mukai, K.; Onaka, T.; Hirofuji, Y.; Ogata, K.; Omatu, S.; Maemoto, T.; Sasa, S. Zinc oxide ion-sensitive field-effect transistors and biosensors. Phys. Status Solidi A 2014, 211, 2098-2104. [CrossRef]

123. Zhao, Z.W.; Lei, W.; Zhang, X.B.; Wang, B.P.; Jiang, H.L. Zno-based amperometric enzyme biosensors. Sensors 2010, 10, 1216-1231. [CrossRef] [PubMed]

124. Lee, K.; Weis, M.; Wei, O.Y.; Taguchi, D.; Manaka, T.; Iwamoto, M. Effects of gold nanoparticles on pentacene organic field-effect transistors. Jpn. J. Appl. Phys. 2011, 50, 041601.

125. Mao, S.; Lu, G.H.; Yu, K.H.; Chen, J.H. Specific biosensing using carbon nanotubes functionalized with gold nanoparticle-antibody conjugates. Carbon 2010, 48, 479-486. [CrossRef] 
126. Mao, S.; Lu, G.H.; Yu, K.H.; Bo, Z.; Chen, J.H. Specific protein detection using thermally reduced graphene oxide sheet decorated with gold nanoparticle-antibody conjugates. Adv. Mater. 2010, 22, 3521-3526. [CrossRef] [PubMed]

127. Mao, S.; Yu, K.H.; Chang, J.B.; Steeber, D.A.; Ocola, L.E.; Chen, J.H. Direct growth of vertically-oriented graphene for field-effect transistor biosensor. Sci. Rep. 2013, 3, 1696. [CrossRef] [PubMed]

128. Cheng, S.S.; Hideshima, S.; Kuroiwa, S.; Nakanishi, T.; Osaka, T. Label-free detection of tumor markers using field effect transistor (fet)-based biosensors for lung cancer diagnosis. Sens. Actuat. B Chem. 2015, 212, 329-334. [CrossRef]

129. Jayasena, S.D. Aptamers: An emerging class of molecules that rival antibodies in diagnostics. Clin. Chem. 1999, 45, 1628-1650. [PubMed]

130. Tuerk, C.; Gold, L. Systematic evolution of ligands by exponential enrichment-RNA ligands to bacteriophage-t4 DNA-polymerase. Science 1990, 249, 505-510. [CrossRef] [PubMed]

131. Ellington, A.D.; Szostak, J.W. Invitro selection of rna molecules that bind specific ligands. Nature 1990, 346, 818-822. [CrossRef] [PubMed]

132. Kim, Y.S.; Raston, N.H.A.; Gu, M.B. Aptamer-based nanobiosensors. Biosens. Bioelectron. 2016, 76, 2-19. [PubMed]

133. Chiu, T.C.; Huang, C.C. Aptamer-functionalized nano-biosensors. Sensors 2009, 9, 10356-10388. [CrossRef] [PubMed]

134. Lee, J.O.; So, H.M.; Jeon, E.K.; Chang, H.; Won, K.; Kim, Y.H. Aptamers as molecular recognition elements for electrical nanobiosensors. Anal. Bioanal. Chem. 2008, 390, 1023-1032. [CrossRef] [PubMed]

135. Farid, S.; Meshik, X.; Choi, M.; Mukherjee, S.; Lan, Y.; Parikh, D.; Poduri, S.; Baterdene, U.; Huang, C.E.; Wang, Y.Y.; et al. Detection of interferon gamma using graphene and aptamer based fet-like electrochemical biosensor. Biosens. Bioelectron. 2015, 71, 294-299. [CrossRef] [PubMed]

136. Lee, H.S.; Kim, K.S.; Kim, C.J.; Hahn, S.K.; Jo, M.H. Electrical detection of vegfs for cancer diagnoses using anti-vascular endotherial growth factor aptamer-modified si nanowire fets. Biosens. Bioelectron. 2009, 24, 1801-1805. [CrossRef] [PubMed]

137. Maehashi, K.; Matsumoto, K.; Takamura, Y.; Tamiya, E. Aptamer-based label-free immunosensors using carbon nanotube field-effect transistors. Electroanal 2009, 21, 1285-1290. [CrossRef]

138. Ohno, Y.; Maehashi, K.; Matsumoto, K. Label-free biosensors based on aptamer-modified graphene field-effect transistors. J. Am. Chem. Soc. 2010, 132, 18012-18013. [CrossRef] [PubMed]

139. Park, J.W.; Na, W.; Jang, J. One-pot synthesis of multidimensional conducting polymer nanotubes for superior performance field-effect transistor-type carcinoembryonic antigen biosensors. RSC Adv. 2016, 6, 14335-14343. [CrossRef]

140. So, H.M.; Won, K.; Kim, Y.H.; Kim, B.K.; Ryu, B.H.; Na, P.S.; Kim, H.; Lee, J.O. Single-walled carbon nanotube biosensors using aptamers as molecular recognition elements. J. Am. Chem. Soc. 2005, 127, 11906-11907. [CrossRef] [PubMed]

141. Wang, C.; Kim, J.; Zhu, Y.; Yang, J.; Lee, G.-H.; Lee, S.; Yu, J.; Pei, R.; Liu, G.; Nuckolls, C.; et al. An aptameric graphene nanosensor for label-free detection of small-molecule biomarkers. Biosens. Bioelectron. 2015, 71, 222-229. [CrossRef] [PubMed]

142. Pacios, M.; Martin-Fernandez, I.; Borrise, X.; del Valle, M.; Bartroli, J.; Lora-Tamayo, E.; Godignon, P.; Perez-Murano, F.; Esplandiu, M.J. Real time protein recognition in a liquid-gated carbon nanotube field-effect transistor modified with aptamers. Nanoscale 2012, 4, 5917-5923. [CrossRef] [PubMed]

143. Grant, S.; Peter, W.; Tal, S.; Matthew, R.L.; Jenna, L.W.; Christopher, A.H.; Adeniyi, A.A.; Vincent, T.R.; Ethan, D.M. Scalable graphene field-effect sensors for specific protein detection. Nanotechnology 2013, 24,355502 .

(C) 2016 by the authors; licensee MDPI, Basel, Switzerland. This article is an open access article distributed under the terms and conditions of the Creative Commons Attribution (CC-BY) license (http://creativecommons.org/licenses/by/4.0/). 